\title{
An Analysis of the Section on Causality in Khojazāda's Tahāfut
}

Muhammet Fatih KIllç"

\begin{abstract}
In this article, the nineteenth section of Khojazāda's (d. 893/1488) Tahāfut, which was devoted to the problem of causality in an example of the works under the same title written during the fifteenth century and composed with the patronage of the Ottoman sultan Mehmed II (d. 886/1481), is subjected to a critical analysis. His discussion follows a critical course with respect to al-Ghazālī (d. 505/1111) in context. This could be detected most clearly in his vindication of Avicenna (d. 428/1037) against al-Ghazālìs accusation of the philosophers' denial of miracles. Moreover, Khojazāda's discussion has certain differences with al-Ghazalli's at both the conceptual and the argumentative levels. The most striking differences at the argumentative level is Khojazāda's grounding of his own conception of revelation and miracles on Avicennia's, rather than al-Ghazāli's, theory of prophethood. By the same token, he offered a practical response to the imputation that the Avicennian system leaves no room for the possibility of miracles. At the conceptual level, furthermore, he distinguished between complete and incomplete causes, in contradistinction with al-Ghazāli, and thereby opened another ground in order to demonstrate the inability of those natures that he viewed as incomplete causes to produce their own effects. On the other hand, Khojazāda concurs with al-Ghazālī that causality did not presume an ontological necessity, yet this condition did not incur defects on the certainty of our knowledge.
\end{abstract}

Keywords: Ottoman thought, Tahāfut genre, causality, Khojazāda, al-Ghazālī, Avicenna.

* I would like to thank TÜBİTAK for the financial support granted at the stage of research, Prof. Robert Wisnovsky, Assist. Prof. Yunus Cengiz and the referees for the diligent readership and the suggestions.

** Assist. Prof., Mardin Artuklu University, Faculty of Letters, Department of Philosophy.

Correspondence: mimfatih@gmail.com 


\section{Introduction}

his study seeks to analyze the Ottoman debates on the problem of causality via Khojazāda's Tahāfut. The tahāfut [incoherence, convolution] genre occupies an intriguing place in the history of Islamic thought, for it was here that speculative theologians and philosophers systematically debated some of the controversial physical and metaphysical issues. Beginning with Abū Hāmid al-Ghazālī's Tahāfut al-falāsifa, his polemic against the philosophers, this genre acquired canonical status with Averroes's (d. 595/1198) Tahāfut al-Tahāfut, which criticized both the perspectives of both groups. Two independent works of this genre joined the canon during the fifteenth century due to Sultan Mehmed II's patronage and active support for revitalizing and continuing the genre: Khojazāda Muṣlih al-Dīn Efendi's Tahāfut al-falāsifa' and the piece by 'Alā' al-Dīn 'Alī al-Ṭūsì (d. 887/1482), variously known as Kitāb al-Dhakhīra or Tahāfut al-falāsifa. ${ }^{2}$ Two more works were added during the sixteenth century: Ibn Kamāl Pāshā's (d. 940/1534) gloss $^{3}$ on Khojazāda's Tahāfut and Muḥyī al-Dīn Qarabāghī's (d. 942/1535) annotation $^{4}$ to the same text. Moreover, Meḥmed Emīn Uskudārī (d. 1149/1736) composed a summary ${ }^{5}$ of Khojazāda's piece during the eighteenth century. Causality, a theme for one of the liveliest debates between these two groups, also appears as a topic in the Tahäfut canon.

In the three centuries from Averroes's Tahāfut to Khojazāda's, the philosophers and theologians did make some conceptual contributions to causality, among them (1) the distinction between complete and incomplete causes, conceptualized by Athīr al-Dīn al-Abharī (d. 663/1265); (2) the true cause and common reason, following the distinction of cause/reason ('illa/sabab) in speculative theology; and the ontological and epistemological causal necessity articulated especially in 'Adud alDīn al-İjī (d. 756/1355) and Sayyid Sharīf al-Jurjānī’s (d. 816/1413) line of thought.

1 Muṣliḥ al-Dīn Khojazāda, Tahāfut al-falāsifa (Cairo: al-Mațba'a al-I'lāmiyya, 1303/1885).

[cf.: http://www.worldcat.org/oclc/122765570 | http://www.worldcat.org/oclc/122726296 | https:// archive.org/details/TehafutFalassifa]

2 'Alī al-Ṭūsī, Kitāb al-Dhakhīra (Hyderabad: Dā'ira al-Ma'ārif al-'Uthmāniyya, 1925); idem, Tahāfut al-falāsifa, ed. Rị̣ā Sa'āda (Beirut: al-Dār al-Ālamiyya, 1981).

3 Shams al-Dīn Ahmad Ibn Kamāl Pāshā, Hāshiya 'alā Tahāfut, Süleymaniye Library, MS Hasan Hüsnü Paşa 1235, 1a-53b. For its Turkish translation, Kemal Paşazâde, Tehâfüt Hâşiyesi (Hāşiya 'alā Tahāfut al-falāsifa), trans. Ahmet Arslan (Ankara: Kültür ve Turizm Bakanlığ1, 1987).

4 Muḥyī al-Ḍin Qarabāghī, Ta'lìqa 'alā Tahāfut al-falāsifa li-Khojazāda, Süleymaniye Library, MS Hasan Hüsnü Paşa 959, 1-17. For a study including a translation and a textual analysis, Abdurrahim Güzel, Karabağ̂i ve Tehâfüt'ü (Ankara: Kültür Bakanlığı, 1991).

5 Mehmed Emin Üsküdârî, Telhîsu Tehâfüti'l-hukemâ, ed. and trans. Kamuran Gökdağ (İstanbul: Türkiye Yazma Eserler Kurumu Başkanlığı, 2014). 
Taking stock of these contributions, the authors contributing to the genre during the fifteenth century and later on considered causality in a framework that went beyond the context of al-Ghazālī and Averroes. Therefore, it becomes apposite to ask what kind of a contribution Khojazāda, who apparently found a greater echo than 'Alī al-Ṭūsī as regards the gloss, annotation, and the summary on his work, made to al-Ghazālì's Tahāfut in terms of causality.

Perusing the research on Islamic philosophy, one comes across several studies concerning causality in al-Ghazālī and Averroes. However, the number of studies dealing with it in the fifteenth-century works, which were of major significance with respect to Ottoman thought, is modest. Furthermore, the greater number of these studies follows a general framework that paraphrases all of the themes, instead of focusing on causality. Therefore, the portrayal of the era's general outlook concerning it notwithstanding, they are insufficient for revealing the nuances wrapped in particular points. Hence, this state of affairs discloses the need for problem-oriented studies concerning the period. ${ }^{6}$

An analytical study on the section discussing causality in Khojazāda's Tahāfut could demonstrate what kind of contribution the said author made to the earlier Tahäfut. ${ }^{7}$ Hence, once the argumentation of the causality section in the texts of al-Ghazālī's and Khojazāda's Tahāfuts are tabulated analytically, the course of the debate on this topic will be demonstrated in a comparative manner based upon the tables thus formed. ${ }^{8}$ As such, the extent of continuity and change in Khojazāda's hand in the Tahäfut genre will be explored within the context of causality.

Cağfer Karadaş's conference paper can be cited as a study focused on the problem of causality conn cerning the period. Even though Karadaş's study makes a significant contribution to literature with respect to Khojazāda's approach to the problem, several major issues like the criticism of al-Ghazāli by Khojazāda, and the Avicennian traces in the work on the matter of the justification of revelation and miracles, were not resolved in the paper for want of a detailed analysis of the argumentation in the relevant section of Tahāfut discussing causality. Cağfer Karadaş, "Hocazâde'nin Tehâfüt'ünde Sebeplilik Meselesi," in Uluslararası Hocazâde Sempozyumu, 22-24 Ekim 2010, Bursa: Bildiriler, eds. Tevfik Yücedoğru, Orhan Ş. Koloğlu, U. Murat Kılavuz, and Kadir Gömbeyaz (Bursa: Bursa Büyükşehir Belediyesi, 2011), 163-73.

7 An exemplary study in this framework is done by van Lit about the problem of God's knowledge of parf ticulars. First having introduced Khojazāda's and 'Alī Ṭūsī’s Tahāfuts as commentaries on al-Ghazālì's Tahāfut, then van Lit subjected the said theme to analytical scrutiny in comparison with al-Ghazālī in this study. L. W. C. van Lit, "An Ottoman Commentary Tradition on Ghazālī's Tahāfut al-falāsifa. Preliminary Observations,” Oriens 43, no. 3-4 (2015): 368-413.

8 In this comparison, the context of Averroes's argumentation is of limited import. For Khojazāda diss cussed the issues in connection with al-Ghazäli's theses at the extent of his text, rather than following from the criticisms of Averroes and his Tahäfut. Therefore, there will not be an argumentation table for Averroes herein. 


\section{Table G: The Structural Analysis of the Seventeenth Thesis in al- Ghazālì's Tahāfut ${ }^{9}$}

The purpose of including table G here is not to display al-Ghazālì's full stance, but to facilitate the reader's comprehension of the common and diverging points made in Khojazāda's Tahäfut, which forms the basis of this study, vis-à-vis alGhazālī. For that reason, the argumentative stages in the table will be briefly mentioned afterward, which will enable the readers to compare them with the course of argumentation in Khojazāda, presented in table $\mathrm{H}$.

\begin{tabular}{|c|c|c|}
\hline $\begin{array}{l}\text { (Introduction) } \\
\text { Main thesis }\end{array}$ & $\begin{array}{l}\text { The relation between what is believed } \\
\text { to be the cause out of habit and what } \\
\text { is believed to be the caused [effect] is } \\
\text { not necessary for us [in our opinion]. } \\
(239,2-3)\end{array}$ & 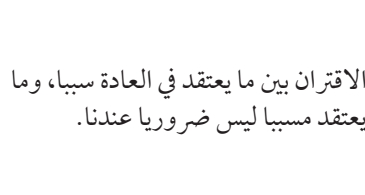 \\
\hline $\begin{array}{l}\text { (Introduction.i) } \\
\text { Reason }\end{array}$ & $\begin{array}{l}\text { Indeed, their relation is, as it has } \\
\text { passed from God the Great's ruling. } \\
\text { He created them in succession, not by } \\
\text { its being necessary in itself, and thus } \\
\text { undoable. }(239,10-11)\end{array}$ & 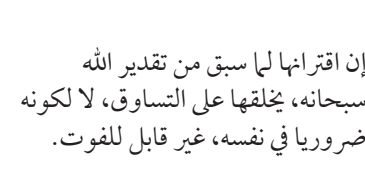 \\
\hline $\begin{array}{l}\text { (Introduction.i.i) } \\
\text { Example }\end{array}$ & $\begin{array}{l}\text { It is the burning of the cotton, for } \\
\text { example, at contact with fire; for we } \\
\text { allow the incidence of the contact } \\
\text { between them without the burning. } \\
(239,16-7)\end{array}$ & 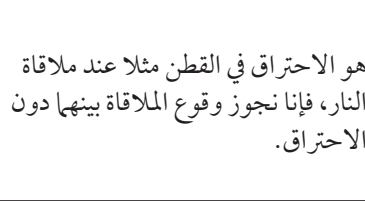 \\
\hline $\begin{array}{l}\text { (1) Counter- } \\
\text { evidence }\end{array}$ & $\begin{array}{l}\text { That the agent of burning is fire only, } \\
\text { and it is an agent by [its] nature, not } \\
\text { by volition. Hence it is not possible } \\
\text { to refrain, for that is its nature, from } \\
\text { acting properly after its contact. ( } 239 \text {, } \\
20-240,2)\end{array}$ & 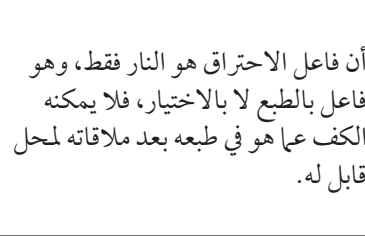 \\
\hline (1.a) Response & $\begin{array}{l}\text { The agent of burning, [...], it is God } \\
\text { the Exalted, either by means of angels } \\
\text { or without any means. But the fire, it } \\
\text { is inanimate, and therefore it has no } \\
\text { action. }(240,3-5)\end{array}$ & 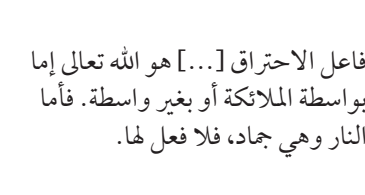 \\
\hline (1.b) Imputation & $\begin{array}{l}\text { There is no evidence of it but the } \\
\text { observation of the event of burning at } \\
\text { [the point of] contact with fire. ( } 240 \text {, } \\
6-7)\end{array}$ & لالاحتر هم دليل إلا مشاهدة حصول النار. \\
\hline
\end{tabular}

9 The numbers of page and line provided in the column for the translation are taken from: al-Ghazāli, Tahāfut al-falāsifa, ed. Sulaymān Dunyā (Cairo: Dār al-Maāāif, 1980), 239-51. 


\begin{tabular}{|c|c|c|}
\hline (1.b.i) Objection & $\begin{array}{l}\text { The observation uncovers the event at } \\
\text { them, and it does not uncover the event } \\
\text { by them. }(240,7-8)\end{array}$ & تدل على الحصول تهلى الحصول عندها ولا \\
\hline $\begin{array}{l}\text { (2) Counter- } \\
\text { evidence }\end{array}$ & $\begin{array}{l}\text { These principles are likewise, things } \\
\text { proceed from them by necessity and } \\
\text { nature, not by way of deliberation } \\
\text { and volition, [like] the emanation } \\
\text { of the light from the Sun. However, } \\
\text { the properties are distinguished } \\
\text { in reception by the variety of their } \\
\text { dispositions. }(242,18-20)\end{array}$ & 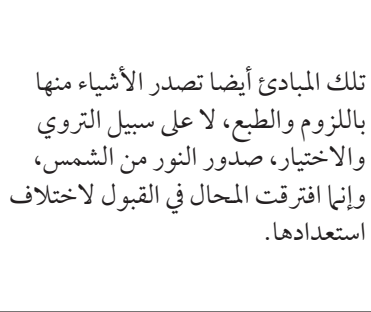 \\
\hline (2.a) Response & $\begin{array}{l}\text { We do not submit that principles do } \\
\text { not run by volition, and that God the } \\
\text { Exalted does not act by will [...] If it } \\
\text { is positive that the agent created the } \\
\text { burning by will at contact of the cotton } \\
\text { with the fire, [then] it is possible to } \\
\text { reason that He did not create the } \\
\text { burning with the existence of the } \\
\text { contact. }(243,12-15)\end{array}$ & 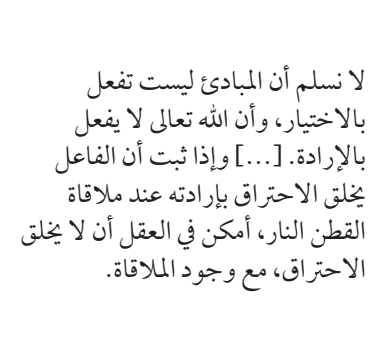 \\
\hline $\begin{array}{l}\text { (2.a.i) Probable } \\
\text { objection }\end{array}$ & $\begin{array}{l}\text { This leads to the perpetration of } \\
\text { outrageous aporias, that is, if it is } \\
\text { denied the necessity of the caused } \\
\text { [effects] [to follow] from their causes. } \\
(243,16-17)\end{array}$ & 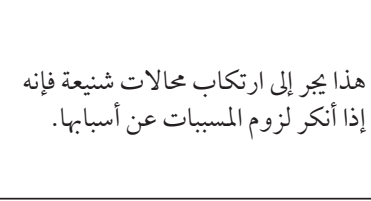 \\
\hline (2.a.i.i) Example & $\begin{array}{l}\text { It might be that some fruits at the } \\
\text { marketplace have turned human. }(244,9)\end{array}$ & قد انقلب إنسانا. بعض إنس الفو اكه في السوق \\
\hline (2.a.i.ii) Response & $\begin{array}{l}\text { Indeed, God the Exalted created for } \\
\text { us the knowledge that these were } \\
\text { possibilities that He would not enact } \\
\text { [...] And the continuation of the habit } \\
\text { of them, times again one after the } \\
\text { other, impressed indelibly on our minds } \\
\text { their duly following of the past habit } \\
\text { permanently. (245, 2-5) }\end{array}$ & 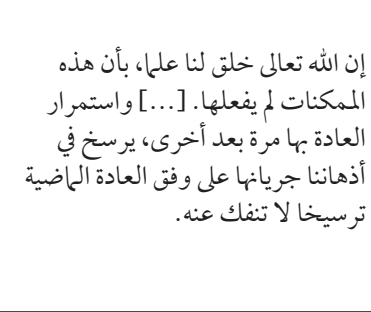 \\
\hline $\begin{array}{l}\text { (2.a.i.iii) } \\
\text { Response }\end{array}$ & $\begin{array}{l}\text { If God disrupts the habit of course } \\
\text { at time, at which the habits were } \\
\text { disrupted, [then] these cognitions will } \\
\text { slip from the hearts and they will not } \\
\text { be created. There is no deterrent to } \\
\text { warrant that the thing be, at the might } \\
\text { of God the Exalted, and that has run } \\
\text { as before. He knew that He would not } \\
\text { enact though within possibility, at } \\
\text { some points. ( } 245,11-15 \text { ) }\end{array}$ & 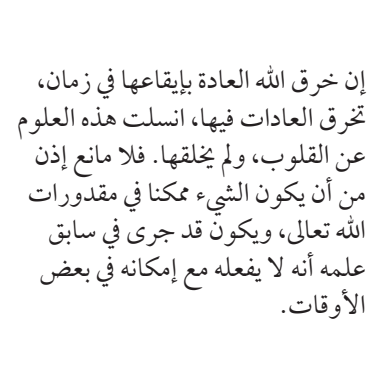 \\
\hline
\end{tabular}




\begin{tabular}{|c|c|c|}
\hline $\begin{array}{l}\text { (2.a.i.iii.i) } \\
\text { Example }\end{array}$ & $\begin{array}{l}\text { We submit that the Prophet may be } \\
\text { cast into fire yet was not burnt, either } \\
\text { by altering the attribute of the fire or } \\
\text { by altering the attribute of the Prophet. } \\
(246,4-5)\end{array}$ & 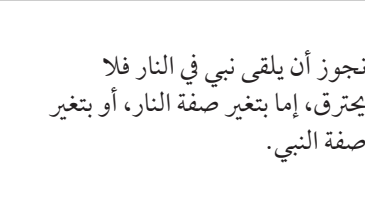 \\
\hline $\begin{array}{l}\text { (2.a.i.iii.ii) } \\
\text { Example }\end{array}$ & $\begin{array}{l}\text { We see [that one] covers himself with } \\
\text { talc then sits in a blazing furnace and } \\
\text { was not affected by fire. [...] Hence, the } \\
\text { opponent's denial of the provenance of } \\
\text { [God's] might on determination of an } \\
\text { attribute amongst the attributes in the } \\
\text { fire, or in the body that would hinder } \\
\text { the burning, is like the denial of [the } \\
\text { one who] did not attest to the talc or its } \\
\text { effect. Wonders and marvels are within } \\
\text { the capabilities of the God the Exalted, } \\
\text { and we did not witness all of them. } \\
\text { ( } 246,10-14)\end{array}$ & 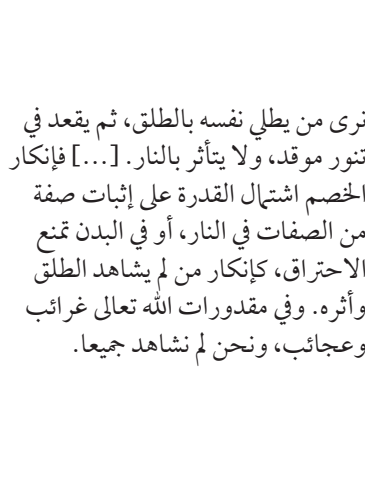 \\
\hline $\begin{array}{l}\text { (2.a.i.iii. } \\
\text { iii) Probable } \\
\text { objection }\end{array}$ & $\begin{array}{l}\text { This proceeds from the Prophet's soul } \\
\text { or another principle amongst the } \\
\text { principles at the suggestion of Prophet. } \\
(247,1-2)\end{array}$ & آخر من المبادئ عند اقتراح النبي. \\
\hline $\begin{array}{l}\text { (2.a.i.iii.iii.i) } \\
\text { Response }\end{array}$ & $\begin{array}{l}\text { Our say on this is like your say on that. } \\
\text { It is appropriate to us and to you to } \\
\text { relate that to God the Exalted, either } \\
\text { without mediation or by means of } \\
\text { angels. }(247,4-6)\end{array}$ & 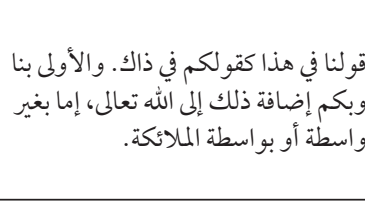 \\
\hline $\begin{array}{l}\text { (2.a.ii) Probable } \\
\text { objection }\end{array}$ & $\begin{array}{l}\text { As a matter of fact, the animal } \\
\text { capacities spill over it from the angels, } \\
\text { who are principles of being. ( } 247 \text {, } \\
16-17)\end{array}$ & 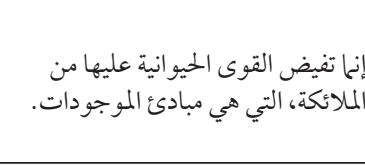 \\
\hline (2.a.ii.i) Example & $\begin{array}{l}\text { Wheat never grows from barley, nor } \\
\text { apples from the seed of pears. ( } 247 \text {, } \\
20-21 \text { ) }\end{array}$ & اللكمّثَّى تفاح من الشعير حنطة ولا من بذر \\
\hline $\begin{array}{l}\text { (2.a.ii.ii) } \\
\text { Response }\end{array}$ & $\begin{array}{l}\text { Their dispositions to receive forms } \\
\text { differ by matters that elude us, and the } \\
\text { understanding of it has not been within } \\
\text { human prowess. }(247,23-24)\end{array}$ & 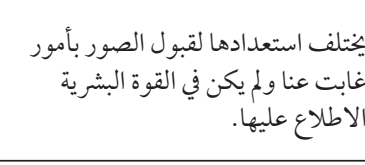 \\
\hline $\begin{array}{l}\text { (2.a.ii.ii.i) } \\
\text { Example }\end{array}$ & $\begin{array}{l}\text { Of which there are generated and } \\
\text { procreated altogether like the mouse, } \\
\text { serpent, and scorpion, and their } \\
\text { generation was from the earth. ( } 247 \text {, } \\
22-23 \text { ) }\end{array}$ & 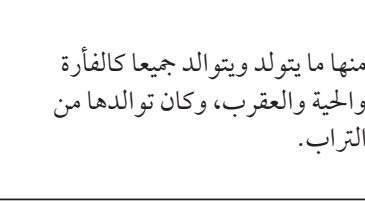 \\
\hline $\begin{array}{l}\text { ( } 3 \text { ) Counter- } \\
\text { evidence }\end{array}$ & $\begin{array}{l}\text { That all that is impossible, however, is } \\
\text { not within [God's] power. }(248,19)\end{array}$ & أن كل محلّ فليس بمقدور. \\
\hline
\end{tabular}




\begin{tabular}{|c|c|c|}
\hline (3.a) Example & $\begin{array}{l}\text { If it refers to the combination of the } \\
\text { negation and the affirmation at one } \\
\text { thing [...] and in fact, these arranged } \\
\text { acts, even playing at His hand, were } \\
\text { created by God the Exalted [...] It } \\
\text { is appropriate that He is capable of } \\
\text { altering the species. Thus, He would } \\
\text { change the essence to accident, } \\
\text { knowledge to power, black to white, } \\
\text { sound to smell, insofar as He could } \\
\text { change the inanimate to animal, } \\
\text { stone to gold, and it would necessitate } \\
\text { likewise innumerable aporias. (248, } \\
22-249,11 \text { ) }\end{array}$ & 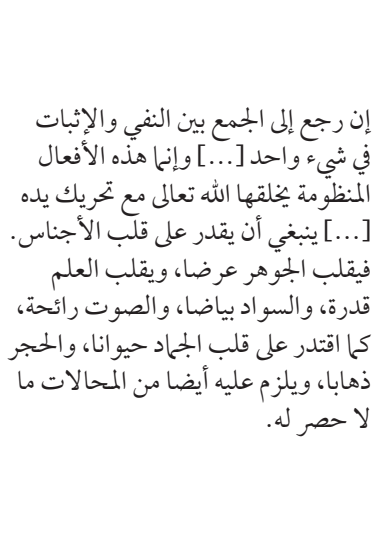 \\
\hline (3.b) Response & $\begin{array}{l}\text { Indeed, the aporia is beyond the } \\
\text { power [of God], and the aporia is the } \\
\text { positivity of the thing together with its } \\
\text { negativity [...] And what does not refer } \\
\text { to these, however, is not aporetic. And } \\
\text { what is not aporetic, then, is within } \\
\text { [God's] might. (249, 12-14) }\end{array}$ & 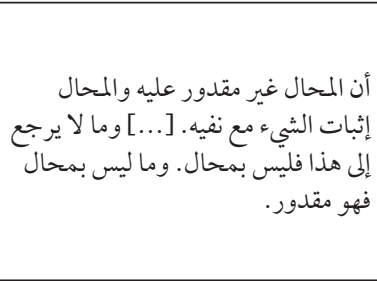 \\
\hline (3.b.i) Example & $\begin{array}{l}\text { It is not admissible for a single person } \\
\text { to be in two places [simultaneously]. } \\
(249,18)\end{array}$ & لا لايجوز كون الشخص الواحد في \\
\hline (3.b.ii) Reason & $\begin{array}{l}\text { It is unintelligible for a thing to become } \\
\text { another thing. }(250,7)\end{array}$ & مصير الشيء شيئا آخر غير معقول. \\
\hline (3.b.iii) Example & $\begin{array}{l}\text { If blackness turns into dusk, for } \\
\text { example, then does blackness remain } \\
\text { or not? Then, if it is gone, it does not } \\
\text { turn into but ceases to exist as such and } \\
\text { something else comes into existence. } \\
\text { [...] Then matter is common and form } \\
\text { is mutable. Likewise, if we say the staff } \\
\text { turned to serpent, and the earth to } \\
\text { animal. (250,7-18) }\end{array}$ & 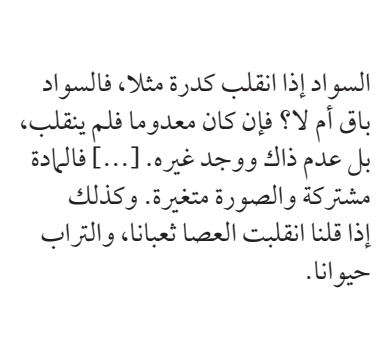 \\
\hline (3.c) Response & $\begin{array}{l}\text { However, God the Exalted moving } \\
\text { the hand of the dead [...] that is not } \\
\text { out of question in itself. We refer the } \\
\text { occurrences to a will making choices } \\
\text { anyway. }(251,1-3)\end{array}$ & 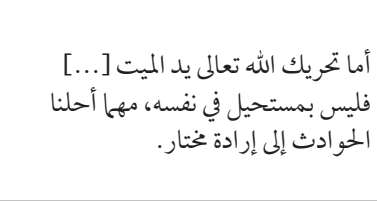 \\
\hline $\begin{array}{l}\text { (3.c.i) Probable } \\
\text { objection }\end{array}$ & $\begin{array}{l}\text { It nullifies with this the statement } \\
\text { [that] the correctness of the act is due } \\
\text { to the knowledge of the agent. }(251,4)\end{array}$ & تبطل به دلالة إحكام الفعل على علم \\
\hline (3.c.i.i) Response & $\begin{array}{l}\text { That the agent at the moment is God } \\
\text { the Exalted, and He is the correct and } \\
\text { the knower of it. }(251,5)\end{array}$ & وهو عالم به. الذآن هو الله تعالى، وهو محكم \\
\hline
\end{tabular}


In the introduction and first stage of the argument, al-Ghazāli refutes the claim that what were conceived to be causes in the physical world had a necessary effect on what were presumed to be their outputs. No certain proof indicates the necessity of such a relation, in his opinion, for there is just a succession between two things that we came to know just by observation. Hence, this does not underpin any evidence indicating a causal necessity between the said two things, but just habits. On the other hand, he does not attempt to demonstrate the lack of any relation whatsoever between the two things in succession. Apparently, his goal here is not to refute the existence of the relation between the cause and its output, but rather to subject the assertion of the necessity of this relation to criticism. ${ }^{10}$

At the second stage, al-Ghazāli criticizes the supposition that everything had particular dispositions that determined how one thing related with other things, ${ }^{11}$ for according to this supposition dispositions were immutable parts of the nature of things and necessarily bore the same consequences under certain conditions, since they did not change. For al-Ghazālì, however, dispositions could be linked to some unexpected occurrence based on the choice of divine will, which surpasses human capacity. Thus the disposition could give off an effect beyond the order of things to which humans are accustomed. But this possibility does not proffer a feeling of ontological mistrust in humans toward the world's smooth operation, for miracles, considered divine creations outside the habitual order of things, were created only on special occasions as opposed to unreservedly and permanently. As a result, the occurrence of events without digression from their past manifestations is impressed upon the human mind. At this point, al-Ghazāli remarks that the aforementioned supposition is admissible, provided that miracles would be based on divine will, while referring to the philosophers' explanations of miracles as originating from the Prophet's self.

At the third stage, he attempts to respond to the philosophers' claim that God can only create that which is possible, meaning that He cannot create that which is impossible. In his response, he first tries to delineate the impossible, which he defines as maintaining both positive and negative judgments on one thing simultaneously. In other words, he closely followed the logical principles of non-contradiction and the impossibility of a third option. ${ }^{12}$ On the other hand, he judged the transformation between the essence and the accident to be impossible due to the 
lack of any common in-between matter. Except for it, he opines that all things are within God's might.

\section{Table H: The Structural Analysis of the Nineteenth Thesis ${ }^{13}$ in Khojazā- da's Tahāfut ${ }^{14}$}

\begin{tabular}{|c|c|c|}
\hline $\begin{array}{l}\text { (1) Counter- } \\
\text { evidence }\end{array}$ & $\begin{array}{l}\text { That the bodies are the effects and the acts } \\
\text { in matter by nature. }(98,8)\end{array}$ & موادها. أن لطئع الأجسام آثارا و أفعالا في \\
\hline (1.a) Example & $\begin{array}{l}\text { Like the burning resulting from the fire at } \\
\text { the cotton. }(98,9-10)\end{array}$ & كالاحتراق الحاصل في القطن من النار. \\
\hline (1.b) Reason & $\begin{array}{l}\text { Those natures have been complete causes } \\
\text { individually in their effects, and have been } \\
\text { incomplete causes that need other things to } \\
\text { join them with the conditions and removal } \\
\text { of the obstacles in order for those effects } \\
\text { to come into being from those natures. } \\
\text { Then, once came into being it completes } \\
\text { the cause and produces the effect without } \\
\text { further ado. }(98,11-4)\end{array}$ & 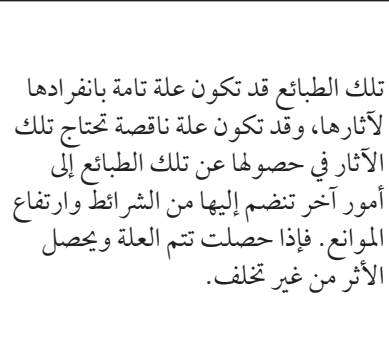 \\
\hline $\begin{array}{l}\text { (1.c) al- } \\
\text { Ghazālī's } \\
\text { claim }\end{array}$ & $\begin{array}{l}\text { Imam al-Ghazāli said: "They [the } \\
\text { philosophers] built their denial on this } \\
\text { basis, some miracles conveyed from the } \\
\text { prophets." }(98,25-6)\end{array}$ & الأنوا انكار بعضياء. الإمام الغزالي وعلى هذات الأصنقولة عن \\
\hline $\begin{array}{l}\text { (1.c.i) } \\
\text { Response to } \\
\text { al-Ghazālì's } \\
\text { claim }\end{array}$ & $\begin{array}{l}\text { We did not see [anything] in a book from } \\
\text { the philosophers that either indicates the } \\
\text { denial of instances of these miracles or } \\
\text { implicates them. (100, 19-20) }\end{array}$ & 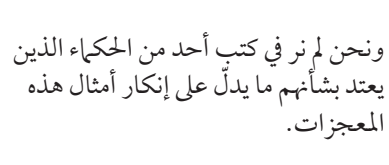 \\
\hline
\end{tabular}

13 This section is erroneously numbered as $18^{\text {th }}$ in 1303 [?] Cairo edition. In his work, Khojazäda discussed the subject under 22 independent sections. However, there are 19 headings in total despite the fact that printed text is complete. For the editor did not number the $13^{\text {th }}, 21^{\text {st }}$, and $22^{\text {nd }}$ theses. That is why, the problem of causality discussed by Khojazāda at the section 19 is under number 18 in this edition.

14 The numbers of page and line provided in the column for the translation refers to the only print edition as of now: see n. 1 above. [cf. 1321/1903 two-volume edition, a reprint of the 1303/1885 edition in different pagination, where Khojazāda's text reads in the margin] 


\begin{tabular}{|c|c|c|}
\hline $\begin{array}{l}\text { (1.c.i.i) } \\
\text { Reason }\end{array}$ & $\begin{array}{l}\text { Their [philosophers'] doyen Avicenna } \\
\text { has disapproved of their ways and } \\
\text { falsified their conduct, whereby he said: } \\
\text { "Don't you ever be distinguished from } \\
\text { the commoners in the way that it was } \\
\text { repugnance by everything. Then that is } \\
\text { indiscretion and fecklessness. The breach } \\
\text { in your falsification, unless you know its } \\
\text { impossibility by evidence, is not far from } \\
\text { the breach in your verification, unless the } \\
\text { evidence is put in your hands. And you } \\
\text { should know that there are wonders in } \\
\text { nature, marvelous [conjunctures] joined } \\
\text { by active sublime powers and passive base } \\
\text { powers."* (100, 23-7) }\end{array}$ & 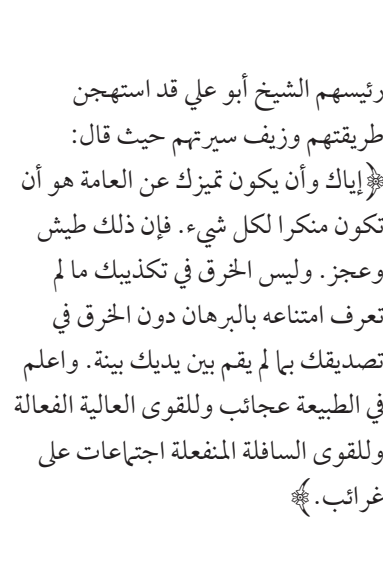 \\
\hline (1.d) Response & $\begin{array}{l}\text { You do not assert that the natures are } \\
\text { complete causes, neither individually nor } \\
\text { together with things supplementing by } \\
\text { the existence of conditions and removal of } \\
\text { obstacles, since it does [not] follow from } \\
\text { the effects. }(98,30-2)\end{array}$ & 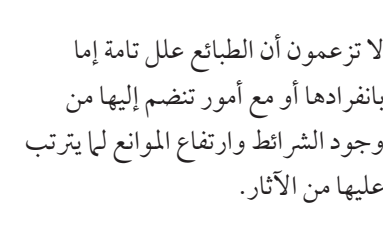 \\
\hline $\begin{array}{l}\text { (1.e) } \\
\text { Imputation }\end{array}$ & $\begin{array}{l}\text { Your only proof of what you mentioned is } \\
\text { just observation always or generally has } \\
\text { sorted evidence that you supposed to be } \\
\text { the cause or the caused. }(98,32-3)\end{array}$ & 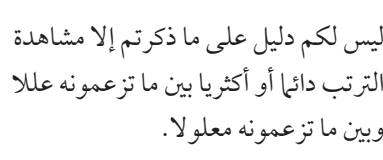 \\
\hline $\begin{array}{l}\text { (1.e.i) } \\
\text { Objection }\end{array}$ & $\begin{array}{l}\text { The arrangement of the thing after the } \\
\text { thing, [whether] always or generally, } \\
\text { is called after a cycle and that does not } \\
\text { evince causality. Why not concede that } \\
\text { the principle was current practice by } \\
\text { nature of the burning after contact with } \\
\text { fire, and thus started the burning, without } \\
\text { that it was by contact with fire? }(98,33 \text {; } \\
99,2)\end{array}$ & 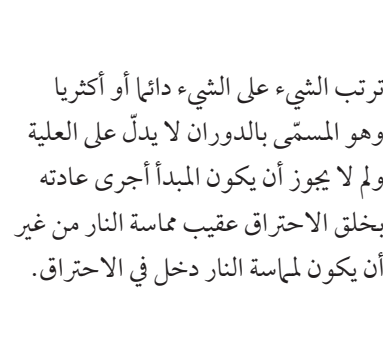 \\
\hline $\begin{array}{l}\text { (2) Counter- } \\
\text { evidence }\end{array}$ & $\begin{array}{l}\text { In fact, the principle is not conceived } \\
\text { of within the current practice, for it } \\
\text { is necessary in itself, not an agent by } \\
\text { volition. The current practice, however, is } \\
\text { conceived of within which it is an agent by } \\
\text { volition. }(99,3-4)\end{array}$ & 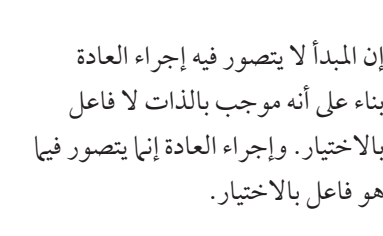 \\
\hline
\end{tabular}

For the version of Avicenna's al-Ishārāt from which Khojazāda cites with deviations in a few words and the omission of two sentences, cf. Ibn Sīnā, al-Ishärāt wa-al-tanbīhāt (al-Tașawwuf), ed. Sulaymān Dunyā (Cairo: Dār al-maāāif, 1968), 4:159-60 (10.31). 


\begin{tabular}{|c|c|c|}
\hline (2.a) Response & $\begin{array}{l}\text { What you called a disposition and the } \\
\text { necessity of emanation, when it [the } \\
\text { principle] is complete and impossibility } \\
\text { without, has to do with the principle's } \\
\text { being necessary in itself. We have } \\
\text { concluded the annulment of your } \\
\text { evidence, as [stated] previously. }(99,5-6)\end{array}$ & 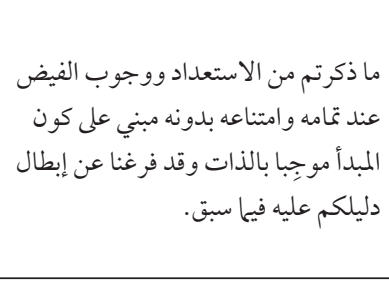 \\
\hline $\begin{array}{l}\text { (2.b) Counter- } \\
\text { claim }\end{array}$ & $\begin{array}{l}\text { That elemental substances are subject }[. . .] \\
\text { to the celestial movements and positions } \\
\text { that may occur due to their dispositions } \\
\text { by forms and accidents. }(99,8-9)\end{array}$ & 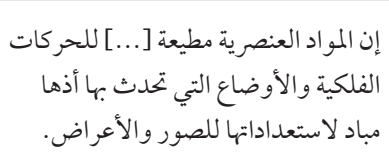 \\
\hline $\begin{array}{l}\text { (2.b.i) } \\
\text { Example }\end{array}$ & $\begin{array}{l}\text { That the books in our rooms do not turn } \\
\text { into virtuous people. }(99,7)\end{array}$ & فضلاء. أنتب في حجر تنا لم تنقلب أناسا \\
\hline $\begin{array}{l}\text { (2.b.ii) } \\
\text { Response }\end{array}$ & $\begin{array}{l}\text { It may be that an exceptional celestial } \\
\text { position occurs that did not occur like } \\
\text { that for thousands of years would require } \\
\text { the emergence of the disposition on the } \\
\text { matter of books that are in our rooms to } \\
\text { take human forms. [...] This possibility } \\
\text { cannot be dismissed by certain proof. (99, } \\
9-12 \text { ) }\end{array}$ & 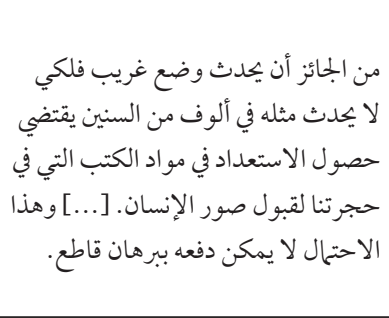 \\
\hline $\begin{array}{l}\text { (2.b.iii) } \\
\text { Response }\end{array}$ & $\begin{array}{l}\text { It is not by trust of knowledge that } \\
\text { the emergence of the effect rests on } \\
\text { disposition [...] Rather, it is required } \\
\text { knowledge [that] God the Exalted created } \\
\text { in us upon a continuation of that habit. } \\
\text { Then if God the Exalted disrupts the habit } \\
\text { in the course of transformation at a time } \\
\text { [when] He disrupts the habits, [then] He } \\
\text { robs these cognitions from [our] mind. } \\
(99,13-7)\end{array}$ & 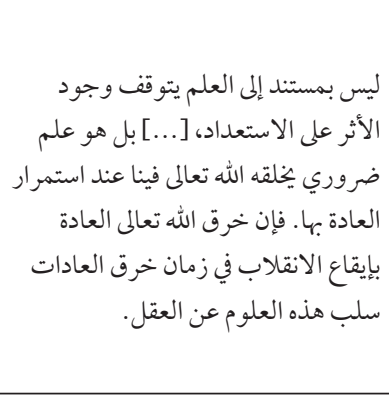 \\
\hline $\begin{array}{l}\text { (2.b.iii.i) } \\
\text { Example }\end{array}$ & $\begin{array}{l}\text { Why not concede that there emerges in } \\
\text { fire, by means that may be exchanged } \\
\text { within the Prophet's soul, an attribute } \\
\text { that prevents the influence on his body } \\
\text { while the particular truth of it [the fire] } \\
\text { lasted, or an attribute that inhibits } \\
\text { the influence of fire on his body? [...] } \\
\text { Transformation of the staff into a serpent, } \\
\text { and the animation of the dead, likewise. } \\
(99,21-7)\end{array}$ & 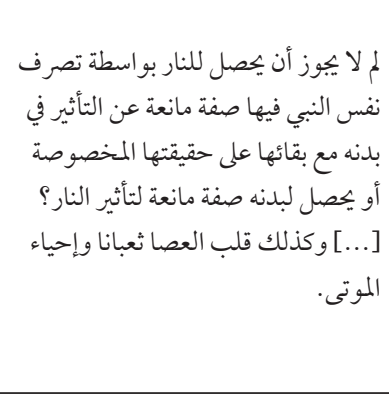 \\
\hline $\begin{array}{l}\text { (2.b.iv) } \\
\text { Response }\end{array}$ & $\begin{array}{l}\text { It has been evident that the dispositions } \\
\text { tread variously that may be neither seized } \\
\text { nor encompassed by human capacities. } \\
(100,5-6)\end{array}$ & تض تبين أن طرق الاستعداد مختلفة لا. \\
\hline
\end{tabular}




\begin{tabular}{|c|c|c|}
\hline $\begin{array}{l}\text { (2.b.iv.i) } \\
\text { Example }\end{array}$ & $\begin{array}{l}\text { Like the frogs that fall with rain } \\
\text { sometimes. That the disposition of the } \\
\text { matter to receive their forms emerges in } \\
\text { the air for a short duration. }(100,3-4)\end{array}$ & 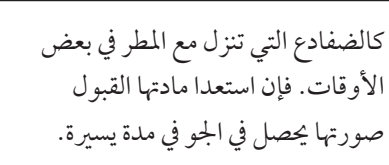 \\
\hline $\begin{array}{l}\text { (2.c) Counter- } \\
\text { claim }\end{array}$ & $\begin{array}{l}\text { If the transformation of the staff into } \\
\text { a serpent is possible, so would the } \\
\text { transformation of the essence into } \\
\text { accident and vice versa be possible. (100, } \\
\text { 11) }\end{array}$ & 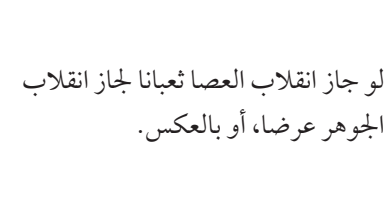 \\
\hline $\begin{array}{l}\text { (2.c.i) } \\
\text { Response }\end{array}$ & $\begin{array}{l}\text { If the essence turns into accident, then the } \\
\text { essence ceases to exist and the accident } \\
\text { comes into existence. Thus one of them } \\
\text { does not turn into the other; rather, one } \\
\text { of them ceases to exist and the other } \\
\text { comes into existence. If it does not cease } \\
\text { to exist but comes into existence with } \\
\text { the accident, then it neither turns into } \\
\text { but [rather] supplements it with another } \\
\text { matter. If it does not cease to exist and the } \\
\text { accident is not there, then it is how it was } \\
\text { and neither transforms. (100, 16-9) }\end{array}$ & 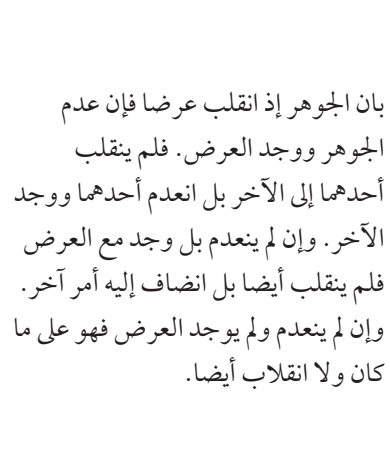 \\
\hline $\begin{array}{l}\text { (3) Counter- } \\
\text { evidence }\end{array}$ & $\begin{array}{l}\text { That the human souls have a cognizance } \\
\text { of what is hidden in dream state. All } \\
\text { people have felt this in their soul by } \\
\text { experience entailing attestation, except } \\
\text { for those who were ill-tempered and short } \\
\text { of imagination and articulation. (100, } \\
28-30 \text { ) }\end{array}$ & 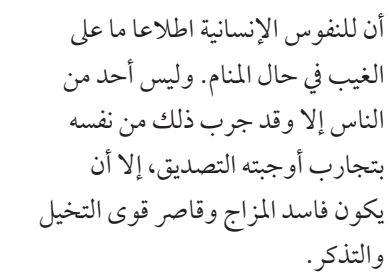 \\
\hline (3.a) Response & $\begin{array}{l}\text { In fact, human souls have a genetic } \\
\text { relationship to sublime principles adorned } \\
\text { with all that was, will be, and currently is. } \\
\text { [...] At that moment [of sleep], it joins by a } \\
\text { spiritual connection with these principles } \\
\text { and portrays some of what is adorned in } \\
\text { these principles in the soul, whereof it } \\
\text { has a disposition to, so that it would be } \\
\text { adorned. }(100,32 ; 101,12)\end{array}$ & 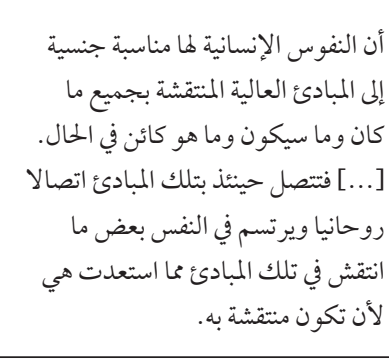 \\
\hline $\begin{array}{l}\text { (3.a.i) } \\
\text { Example }\end{array}$ & $\begin{array}{l}\text { [...] Then observation sets in. That is the } \\
\text { true dream. }(101,15)\end{array}$ & الصادقة. \\
\hline
\end{tabular}




\begin{tabular}{|c|c|c|}
\hline (3.b) Response & $\begin{array}{l}\text { That the souls diverse in stations of } \\
\text { strength and feebleness are significantly } \\
\text { distinct. [...] Then it occurs to this soul } \\
\text { [strong at the capacity of imagination] } \\
\text { while awake at the same rate what occurs } \\
\text { to the sleepers linked with distinct } \\
\text { principles and some of what is within } \\
\text { impressed on them, whereof it was and } \\
\text { will be from the hidden. }(101,24-33)\end{array}$ & 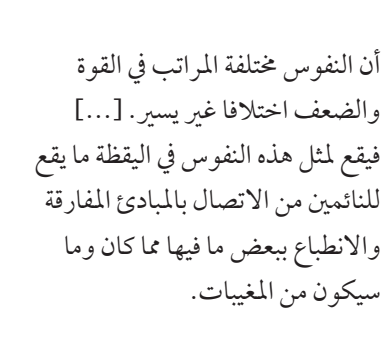 \\
\hline $\begin{array}{l}\text { (3.b.i) } \\
\text { Example }\end{array}$ & [...] That was the express revelation. $(102,4)$ & [...] كان ذلك وحيا صريحا. \\
\hline (3.c) Response & $\begin{array}{l}\text { In fact, the reflections of the souls may } \\
\text { have been causes for the occurrence of the } \\
\text { events without that there has been any } \\
\text { corporeal cause hereby. }(102,5)\end{array}$ & 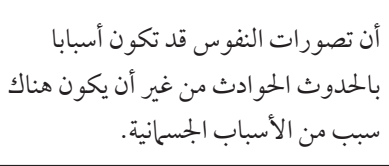 \\
\hline $\begin{array}{l}\text { (3.c.i) } \\
\text { Example }\end{array}$ & $\begin{array}{l}\text { That the melancholy and the wrath [as } \\
\text { reflections of the soul] foster heat in the } \\
\text { body. }(102,6)\end{array}$ & أن الغمّ و الغضب يو جبان سخونة البدن. \\
\hline (3.d) Response & $\begin{array}{l}\text { It is not farfetched that some of the } \\
\text { strong human souls really corresponded } \\
\text { with an essential power. [...] The influence } \\
\text { of it [the strong souls] surpasses its body. } \\
\text { Thus, it impinges on the material objects } \\
\text { just as it does on its body, by the token } \\
\text { of its abundant power that it is a soul [as } \\
\text { if] governing the entire material world or } \\
\text { some of it. }(102,8-11)\end{array}$ & 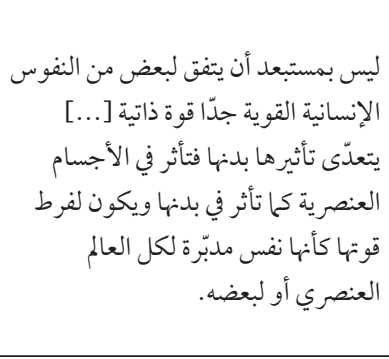 \\
\hline $\begin{array}{l}\text { (3.d.i) } \\
\text { Example }\end{array}$ & $\begin{array}{l}\text { The affectations from it [the soul] take } \\
\text { place in the world of genesis and decay. } \\
\text { Earthquakes, hurricanes, and eclipses } \\
\text { occur. The animal becomes inanimate and } \\
\text { the inanimate animate, even exceptions } \\
\text { from the supernatural transmitted from } \\
\text { the prophets, may peace be upon them. } \\
(102,12-4)\end{array}$ & 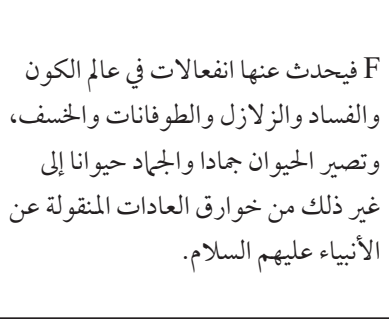 \\
\hline
\end{tabular}

\section{The First Stage of Khojazāda's Argumentation: The Distinction of Complete and Incomplete Causes and the Attempt to Salvage Avicenna from al-Ghazālī's Imputation}

The most striking concept, when compared the counter-evidence and its implication at the first stage of table $\mathrm{H}$ to the content at the first stage of table $\mathrm{G}$, is the complete cause that Khojazāda employs when discussing the matter of nature's deployment of a certain causal effect. In paragraph $\mathrm{H}(1 . \mathrm{b})$, where he states the reason 
of the counter-evidence, Khojazāda expresses that the cause in a necessary causal relation with its effect is a complete cause that contains all the causal conditions within itself. When compared to his response in $\mathrm{H}(1 . \mathrm{d})$, one sees that he did not deny the ontological relation between the complete cause and its effect, because here he was delineating what counts as a complete cause. In his opinion, nature in itself cannot be considered a complete cause. Ergo, it could not necessitate its effect. Buy this point begs the question of what he owed to his predecessors as regards the conceptual content of a complete cause at the aforementioned stage of his argumentation and what he thought about it.

The complete cause, a significant catchword of the post-classical Islamic thought that emerged after Avicenna, meant "the cause from which its effect is inalienable" and was employed in this sense since Abū al-Barakāt al-Baghdādī (d. 547/1152). ${ }^{15}$ Afterward, one notices that al-Suhrawardi (d. 587/1191) defined it as "the cause of a thing, all its parts, its existence, and its actualization" in his Lamahăt. ${ }^{16}$ The complete cause became a key concept of the debates on causality by Athīr al-Dìn al-Abhari. In addition to employing the complete cause in the sense of the necessary cause of a thing's existence, al-Abhari also uses the incomplete cause, which was conceived of as part and parcel of the complete cause and exhibiting causal efficacy, although not necessitating the existence of a thing by itself. ${ }^{17}$

We may suggest that his usage made a significant contribution to standardizing the distinction between complete and incomplete causes, which became an almost quintessential element of the subsequent debates on causality. One comes across this distinction as part of the standard conceptual toolkit in the works of philosophy and speculative theology starting from the second half of the thirteenth century. ${ }^{18}$ Although there were some slight nuances in these two terms' definitions, general definitions for both sets can be elicited by following these debates. While the cause, which was a factor in a thing's existence but insufficient by itself to engender its being, is called the incomplete cause, the complete cause engenders a

15 Abū al-Barakāt al-Baghdādī, al-Kitāb al-Mu'tabar fĩ al-ḥikma (Hyderabad: Jam‘iyya Dā’ira al-Ma'ārif al-'Uthmāniyya, 1357/1938), 1:110, 3-8.

16 Shihāb al-Dīn Yaḥyā al-Suhrawardī, Kitāb al-Lamaḥāt, ed. Emile Maalouf (Beirut: Dar al-Nahār, 1969), 133, 17-8.

17 Athīr al-Dīn al-Abharī, Kashf al-ḥaqā’iq fì taḥrīr al-daqā’iq, ed. Hüseyin Sarıoglu (İstanbul: Çantay Kitabevi, 1998), 293, 10-294, 4.

18 For instance, cf. Najm al-Dīn Kātibī and Shams al-Dīn Mubārakshāh, Hikma al-ayn wa-al-sharḥ (Mashhad: Dānishgāh-i Firdawsī, 1974), 174, 13-175, 3; Shams al-Dīn Shahrazūrī, Rasā̉il al-Shajara alilāhiyya, ed. Necip Görgün (İstanbul: Elif Yayınları, 2004), 135, 21-136, 8; Sa‘d al-Dīn al-Taftāzānī, Sharḥ al-Maqāṣid, ed. Abd al-Raḥmān 'Umayra (Beirut: 'Ālam al-Kutub, 1998), 2:80, 18-81, 3. 
thing's being without recourse to any other cause. The important matter here is what the complete cause, which forms its effect, involves. That is, if there were a complete cause, then the relation between the cause and its effect would be indissoluble. In Sharh al-Mawāqif, written when this distinction was already common, Sayyid Sharîf al-Jurjānī has this to say about the complete cause:

\begin{abstract}
What a thing required all with respect to its content and existence or just existence is called complete cause. The word "all" intimates the requirement of the presence of synthesis in the complete cause. [However] this is not a must. In fact, the author's [al-Ijji] word suggests that: The complete cause is sometimes the efficient cause. It is either alone like the necessary agent [al-fä'il al-müjib] that a simple thing emanates from it, or as in the independent agent [al-fä́il al-mukhtār] that the simple thing ensuing from it is together with the objective, when there is no condition the existence of which demands attention nor an obstacle the non-existence of which has to be noted.
\end{abstract}

Sometimes the complete cause is the combination of the aforementioned four causes, as in the compound ensuing from the independent agent. Sometimes it is the combination of the three, as in the compound emanating from the necessary agent. ${ }^{19}$

This passage, which overviews the complete cause's probable content, defines it, on the first hand, as the totality of things that are necessary as regards the content and the existence of a thing or the existence alone. But in his opinion, this state does not always mean that the complete cause must be the cause of a compound entity consisting of matter and form, because the complete cause can sometimes be regarded as an individual cause. al-Jurjānī exemplifies it by the necessary efficient cause, that is, the cause of simple existence. The necessary agent turns into a complete cause, ipso facto, for it lacks an objective that would impel it to act and therefore necessitates its effect. Nevertheless, al-Jurjānī does not fail to add the clause of the existence of conditions and the non-existence of inhibitors as implicating causality but not forming a kind of cause in itself, concerning the individual complete cause. On the other hand, pointing out the possibility that the complete cause may consist of two causes, the efficient and the final, he offers the example of the independent efficient cause coupled with an objective that impels it toward action. As such, the complete cause is composed of the juxtaposition of the agent and the objective. The later elaborations, which al-Jurjāni presented about the content of the complete cause, entails that the complete cause of the compound be made of matter and form. Given that it follows, if we speak of an independent agent 
accompanied by the objective as the causes of the compound, then we come across a chart of complete causes in which each of the four causes is present. However, if the necessary agent is unaccompanied by the objective at the compound, then the complete cause comprises matter, form, and agent.

Khojazāda employs the concept of complete cause in the first part of his Tahāfut, where he inquired into the philosophers' claim that God is motive in itself ( $m \bar{u}$ jib bi-al-dhāt), meaning thereby that its effect is inalienable. In other words, it necessitates its effect, as in the nineteenth thesis. ${ }^{20}$ Yet he neither provides a comprehensive answer in the Tahäfut concerning the complete cause's definition or content, nor can one uncover elaborations concerning the complete cause's content in his gloss ${ }^{21}$ on al-Abharī's Hidāyat al-ḥikma or his annotation ${ }^{22}$ on al-Jurjānī's Sharh al-Mawāqif, excluding the ontological topics. In order to find relatively unequivocal expressions on how Khojazāda views the content of a complete cause, one should consult his short treatise Kalimāt fì baḥth al-illa wa-al-ma'lūl, which discusses the anteriority-posteriority between the cause and the caused. Here, he defines causality as the thing that one entity needs for its own existence ${ }^{23}$ and the complete cause concerning complex entities as the cause formed by juxtaposing the agent, the objective, the matter, and the form. ${ }^{24}$ When these expressions concerning the causality and the complete cause are put together in a greater framework, one could suppose that the complete cause is regarded as the cause that supplied everything needed for it to exist.

Although this explanation shows his connection with the earlier philosophers and theologians, it remains wanting vis-à-vis al-Jurjānī's elaborate scheme on the content of the complete cause, because it only deals with the implications of the complete cause constituting the reason of a compound existence by juxtaposing four causes. ${ }^{25}$ However, venturing to suggest that Khojazāda only conceived of

20 Khojazāda, Tahāfut al-falāsifa, 6, 3.

21 Cf. Emre Önal, "Hocazade ve Haşiya ala Şarh Hidayet al-Hikma Adlı Eseri” (MA thesis, Marmara Unii versity, 2006).

22 Cf. Khojazāda, Ta'līqāt 'alā Sharḥ al-Mawāqif, Atıf Efendi Library MS 1219, 1a-104b.

23 “al-'Illiyya laysat illā mā yaḥtāju ilayh al-shay' fī wujūdih.” Cf. Khojazāda, Kalimāt fì bahth al-ílla wa-alma'lūl, Süleymaniye Library, MS Esad Efendi 1161, 99a.

24 "Wa ammā al-'illa al-tāmma allatī hiya majmū' al-umūr al-arba'a [...] a'nī al-fā'il wa-al-ghāya wa-al-mādd da wa-al-sūra 'illa." Ibid.

25 A contemporary of Khojazāda's, Sinān Pasha's short treatise titled identically to Khojazāda's within the same miscellany provides a full treatment of the complete cause, also considering the debates of the $13^{\text {th }}$ and $14^{\text {th }}$ centuries. According to Sinān Pasha, it is more proper to define the complete cause as the independent efficient cause that would not need any other thing to render its caused with existence, 
this implication might be a bit too much. Thus, it would be more appropriate to conclude that no certain proof of his thought about what the complete cause was exists. Nonetheless, it might be supposed, with respect to Khojazāda, that the relation of the complete cause that emerged from that particular juxtaposition to its effect is not refuted when the perspectives in Tahäfut and the said treatise are considered together.

Another matter that indicates Khojazāda's perspective is the title he picked for the nineteenth thesis: "The refutation of the claims concerning the necessity of the juxtaposition of the common reasons and the effects and the impossibility of their dissolubility." 26 The most striking aspect here is his employment of the concept of reason with the qualification of "common," although the text itself made use of cause, and his thinking on the alienability of simple reason from the effect. It seems that he distinguishes cause and reason and views the former as superior in terms of engendering its effect.

While the concepts of cause and reason were not distinguished with respect to strengthening/weakening the causal relations for the greater part in Avicenna and the Peripatetic school, the speculative theologians of the classical period used both terms in terms of their ability to engender the effect. ${ }^{27}$ The same usage can also be found in the post-classical theologians who inherited Avicenna's legacy. The definitions of reason and cause in al-Jurjānī's Ta'rīfät clearly demonstrate the semantic difference:

The dictionary definition of the reason is what takes one to the goal. Its terminological meaning is that it takes one to the end but has no influence on the end. ${ }^{28}$

Cause is what the existence of one thing depends on. Cause is external to the said thing and active on its existence. ${ }^{29}$

rather than an assembly of four causes and the causal conditions. Cf. Sinān Pāshā, Kalimāt fì baḥth al-illa wa-al-ma'tūl, Süleymaniye Library, MS Esad Efendi 1161, 98a. It could be supposed that this explanation is more articulate than Khojazāda's for the inclusion of the implication of the "independent efficient complete cause" and Sinān Pāshā's own preference concerning the content of the complete cause.

"Fĩ ibțāl qawlihim bi-wujūb al-iqtirān wa imtina' al-infikāk bayn al-asbāb al-'ādiyya wa-al-musabbabāt." Khojazāda, Tahāfut al-filāsifa, 98, 7-8.

27 Osman Demir, Kelâmda Nedensellik: İlk Dönem Kelâmcılarında Tabiat ve İnsan (İstanbul: Klasik, 2015), 23-35.

28 Sayyid Sharīf al-Jurjānī, al-Tárīfāt, ed. 'Abd al-Raḥmān 'Umayra (Beirut: 'Ālam al-Kutub, 1987), 155, 5-6.

29 Ibid., 199, 12. 
Even though the role of reason is patent in the context of these definitions, it means that it has no agency as regards furnishing a thing with existence. On the other hand, the cause appears as an agent rendering its effect. The clause of "being external to its effect" in al-Jurjānî's definition of cause shows that cause marks either the efficient or the final cause or both, for in the Avicennian categorization of internal-external causes and the causes of content and being, matter and form are categorized under internal causes and the causes of content, whereas the efficient and final cause is classified under the external causes and the causes of being. This assessment indicates that a thing's content does not necessitate its being and that it needed at least one efficient reason in order to exist. ${ }^{30}$ Preserving the semantic difference between reason and cause, it seems that al-Jurjānī makes use of the classical-era theologians' distinction between reason and cause made on the one hand, and the view, in connection with Avicenna, that the reason of being has to be distinct from its effect. The qualifier of common (al-'ādiyya), which Khojazāda used in connection with reason in the title of the nineteenth thesis, can also be attested to in al-Jurjānī's Sharh al-Mawāqif, where he confirms his elaboration in Tárīfāt by writing that common reason had no agency at all in the causal relation (al-asbāb al-'ádiyya ghayr mu'aththirāt aṣlan). ${ }^{31}$

Considering his conceptual preferences in the title and the content, it could be supposed that Khojazāda assumed a manner similar to that of the theological school's distinction of reason-cause. This manner is evident as regards the statement in H(1.d) - that the natures immanent to things cannot be considered complete causes - in addition to Khojazāda's use of reason in the title of nineteenth thesis. According to this, reason is conceivably distinct from its effect, whereas the complete cause, in contradistinction to the nature immanent to its effect, appears as an active force in the existence of its effect. Therefore, from his viewpoint, while the causal relationship in the sense of the activity of common reason might be slight, the same standing does not hold for the complete cause. ${ }^{32}$ Nonetheless, one

32 In the introduction of his gloss on Khojazāda's Tahäfut, even though he contents with the theological issues to the exclusion of the problem of causality, Ibn Kamāl comments on the expressions Khojazāda used in the title of the 19th thesis from the perspective of the philosophers. Since he treats the issue in the context of philosophers, he does not distinguish between reason-cause, but uses both the common and the true attributes with respect to the word reason (al-asbāb al-'ädiyya-al-asbāb al-haqiqiyya). According to Ibn Kamāl, one of the outstanding differences between the theologians and the philosophers on the problem of causality is the subject of which reasons are common and which are true. As such a philosopher could concede that there is no indissoluble relation between the common reason and its effect. Cf. Ibn Kamāl, Hāshiya 'alā Tahãfut, 4b, 12-7; the same passage in Turkish translation: Kemal Paşazâde, Tehâfüt Hâşiyesi, 31. 
should note that Khojazāda makes no certain claim to the ontological necessity of the relation of the complete cause with its effect on the physical plane.

Another remarkable matter at the first stage of Khojazāda's argumentation in $\mathrm{H}(1 . c . \mathrm{i})$ is his attempt to salvage the philosophers, especially Avicenna, from alGhazālī's imputation. In fact, in G(2.a.i.iii.iii.i) al-Ghazālī concedes that there was no significant difference between the views of philosophers and theologians on miracles. But his comments in the introduction to the sections related to nature, right before the seventeenth thesis, suggest that the notion of causal necessity would inevitably conclude the impossibility of miracles. ${ }^{33}$ Apparently, Khojazāda takes these statements into account and tries to demonstrate their falsehood with a quotation from Avicenna's al-Ishārāt in H(1.c.i.i). Indeed, Avicenna clearly states that the passive causal order of things might take a different course, although rare, by the agency of the higher beings in the said passage. Therefore, he continues, human beings have to accept miracles because of the difficulty of enclosing higher beings acting on the causal order.

Khojazāda's explanation, with direct reference to Avicenna, can be taken as evidence of his view on miracles, which was more conscientious and attentive than that of al-Ghazālì. However, one must bear in mind that during the three centuries separating these two men, the Avicennian school survived and even prospered within the discipline of speculative theology, and a doctrine formed that Avicenna was a founding father, primarily due to Fakhr al-Dīn al-Rāzī (d. 606/1210). As a matter of fact, the paraphrase of the philosopher's view preceding Avicenna's in H(1.c.i.i) clearly shows that he read al-Rāzī's commentary on this passage and was impressed by those comments that treated Avicenna as the verifier in this context. The obvious evidence of this influence is his direct quotation of the expression "Avicenna has disapproved of their ways and falsified their conduct (Abū 'Alì qad istahjana țariqqatahum wa zayyafa sīratahum)"34 in H(1.c.i.i) from al-Rāzī's commentary on al-Ishārāt.

The nuance contained within Khojazāda's stance is that he includes the verifier's standing within the Tahāfut genre initiated by al-Ghazālī. However, the subsequent Ottoman Tahāfut texts do not assess Khojazāda's attempt. This might be attributable to the absence of sections related to nature, including the topic of causality in Ibn Kamāl's gloss or Qarabāghī's annotation. But the disregard of Khojazāda's response in Uskudārī, ${ }^{35}$ who summarized Khojazāda's Tahāfut while

34 Fakhr al-Dīn al-Rāzī, Sharh al-Ishārāt wa-al-tanbīhāt, ed. 'Alī Riḍā Najafzāda (Tehran: Anjuman-i Āṭhāā wa Mafākhir-i Farhangī, 2005), 2:664, 14-5.

35 Üsküdârî, Telhîsu Tehâfüti'l-hukemâ, 245-9. 
presenting al-Ghazālī's imputation in the relevant part where he summarized the nineteenth thesis, indicates that he either read Khojazāda inattentively or, more optimistically, leaned toward al-Ghazālī's standpoint.

Khojazāda's critical attitude toward miracles in H(1.c.i) is not attested to in the context of the debate on justifying causality in $\mathrm{H}(1 . e)$. There, his stance parallels al-Ghazālī's claim in G(1.b) that the philosophers had no evidence, except for observation, when it came to affirming causal relations. The claim, the most visible form of which can be seen in al-Ghazālī's criticisms, that causality was justified by observation according to the philosophers, cannot be maintained once Avicenna's texts are consulted, for in them he manifestly expresses the view that the senses do not provide certain knowledge in terms of justifying causality. In his opinion, causality can only be proven in the field of metaphysics. Thus, the necessary relation between cause and effect in this perspective has to be searched for in the metaphysical nature of necessity, rather than in the necessity of nature. ${ }^{36}$ However, it appears that Khojazāda did not keep to his stance on miracles on this matter, but rather reproduced al-Ghazāli's claim. This might be due to the continuation of the claim made by such post-Ghazālī Ash'arite theologians as al-Rāzīin and al-Jurjānī. ${ }^{38}$

Khojazāda's conceptual contribution in H(1.e.i) to the context of al-Ghazālì is dubbing the serial events as cycle (al-dawarān), which the latter called habit (al'áda), as in G(2.a.i.ii). The cycle, vis-à-vis habit, can be regarded as the token of a stronger affirmation of the causal relation, for one can suppose that customs and habits change more than things that continually revolve in cycles. Hence, in alMawāqif 'Aḍud al-Dīn al-İjī employs the "necessity of the cycle" (wujūb al-dawarān) 39 in his discussion of causality in human action, but adds that this does not necessitate any relation between the cause and the effect. Therefore, al-İjī may have supplied the context for Khojazāda's conceptual choice. Nevertheless, one must be reminded that it approximates the meaning of "the continual flow of time or events as accustomed" 40 as it was in the conception of habit, that shows no significant digression from the context of al-Ghazālì.

Ibn Sīnā, al-Mabda' wa-al-ma'ād, ed. 'Abd Allāh Nūrānī (Tehran: Mu'assasa-i Muțāla'āt-i Islāmī, 1363/1984), 2:12-7. For the perspective of Avicenna on the justification of causality and the debates on it, cf. K1lıç, “İbn Sînâ'nın Sebeplik Teorisi," 66-70.

38 Ömer Türker, “Giriş: Seyyid Şerif Cürcânî Düşüncesi," in Şerhu'l-Mevâkıf: Mevâkıf Şerhi, trans. Ömer Türker (İstanbul: Türkiye Yazma Eserler Kurumu Başkanlığı, 2015), 1: 78-9.

39 al-Jurjānī, Sharh al-Mawāqif, 8:170, 17-8.

40 Ibn Manẓūr, Lisān al-'arab (Beirut: Dār Ṣādir, 1994), 4:296. 


\section{The Second Stage of Khojazāda's Argumentation: The Critique of the Necessary in Itself and the Reception of the Dispositions in the Physical Relations}

The second stage of Khojazāda's argumentation is discussed with respect to two different conceptual frameworks: (1) the issues of necessary in itself ( $f \bar{a}$ ' $i l ~ b i-$ al-dhāt) and (2) independent power (al-qādir al-mukhtār), and whether the dispositions could be enclosed. This is pertinent to the epistemological aspect of causality. As Ibn Kamāl pointed out, the philosopher's understanding of the irreversibility of cause and effect originates from the view of God being the motive in itself ["unmoved mover"] and imposes a necessity (ijjāb) for God's acts. ${ }^{41}$ Therefore, it is part of the discussion of natural causality as well, for it points out the metaphysical roots of deterministic causality. In contradistinction with al-Ghazālī, Khojazāda reserved a separate section for the criticism of the view that God necessarily engenders the existence of things. For this reason, he does not go into further detail here but only refers the reader to the first part of the book, as in $\mathrm{H}(2 . \mathrm{a})$.

In the first part of his Tahäfut, Khojazāda first outlines the perspectives of the theologians and the philosophers with respect to the issue and tries to identify the points of contention:

Muslims abiding by Islamic law and schools of law assumed the view of God the Exalted as being an independent power. It means that the non-existence of the world is as equally possible as its existence. Moreover, none of the options impinges on His essence in the sense of being inalienable from Him. [As a matter of fact,] His choice to act happens with His will. [This view is] contrary to philosopher's view on this subject. In their view, God is necessary in itself. But then, God's being in action is not like the fire burns or the sun rises, like the things of corporeal nature that acts compellingly. On the contrary, it means that $\mathrm{He}$ is complete in His agency. Thus, considering His knowledge what $\mathrm{He}$ caused and the things emanating from Him, it becomes necessary for things fully disposed to being without any intention or circulation of demand to occur, for He is truly bountiful and absolutely eminent.

[Some] supposed that there is no dispute between the theologians and the philosophers on the matter of God the Exalted being an independent power and that both parties concurred on this matter. [According to them,] the dispute in between is just on the point whether the divine act united power and will. Philosophers embrace the view that the act is contiguous with power and will, for in their opinion the effect does not regress to the complete cause. However, the theologians defend the view that the act should regress to will and power. For the absence of the act requires the existence of an intended state. Otherwise, it would request the existence of an already extended being. 
[But the thing they supposed] is not true. On the contrary, the dispute between us and them, concerning power in the sense of the possibility to act and not to act, is certain because the philosophers suggest that the imagination (representation) of the order of all beings in eternity are within the knowledge of God the Exalted in sequenced and finite moments. In their opinion, whatever is entitled to partake of all those moments has to be there by the merit of its essence, and [thus] its retreat from there is inconceivable. So this order should spread along this arrangement and particularity because its non-emanation is basically impossible. Philosophers call it the primordial providence. Some others name it the will. We, however, concede the possibility of the non-activity of God and the non-necessity of emanation and emergence. What we mean by the necessity of emergence is that the non-activity of God cannot be regarded as a lack unbefitting the supreme lord. Sure, one could come across expressions that intimate His independent power in the words of philosophers. But this does not signify his being in and out of action as the theologians stipulated; rather, it means He acts if He wills [to do so], and remains, if not. Both parties agree on this meaning. But the philosophers argue that God's will to being in action is necessary in itself and, therefore, the will and the act is inseparable. The truth of the first of these conditional propositions is necessary; however, the truth of the second conditional proposition is impossible. ${ }^{42}$

In this passage, Khojazāda imparts information about the different views between the philosophers and the theologians concerning the necessary in itself and the independent power. In the first paragraph, the expression suggesting that the philosophers' notion of necessary in itself in the divine act is unlike that in the things of corporeal nature, like fire burns, can be taken as Khojazāda's attempt to ease the philosophers' rigid approach. Hence, in his gloss Ibn Kamāl supposes that it would turn into a relation of natural causal necessity between God and His work, as in the instance of fire and cotton, once the notion of necessary in itself is adopted, ${ }^{43}$ and further claimsed that Khojazāda's expression is misleading. On the other hand, Khojazāda criticizes the attempts to reconcile the philosophers' and the theologians' perspectives on the issue and distances himself from that position. In contrast to his reconciliatory attitude on the subject of miracles, in the second paragraph of this passage he disapproves of any attempt to reduce this controversy to whether the divine act is contiguous with power and will or not. Khojazāda's criticism here is directed mainly at Naṣir al-Dīn al-Ṭūsì (d. 672/1273), the first and foremost proponent of this perspective. ${ }^{44}$ al-Jurjānì also points out a similar ap-

44 In his summary of al-Rāzì's Muhașșal, Țūsĩ argued that the philosophers did not deny the divine power and will, but that the two had to be contiguous with the divine act. Cf. Nașī al-Dīn al-Ṭūsī, Talkhīṣ alMuḥașṣal, ed. 'Abd Allāh Nūrānī (Tehran: Mu’assasa-i Muțāla'āt-i Islāmī, 1980), 269, 15-270, 2. 
proach as another interpretation. ${ }^{45}$ But Khojazāda states that the said controversy is deeper than that and that the notion of necessary in itself allows no room for the state of God's inactivity, whereas the notion of independent power accommodates it.

The same emphasis comes to the fore once more in the discussion of how both parties understood the principle of "God acts if He wills, and remains if not" related in the final section. As follows, philosophers mean by this principle that (i) the will linked to God's volition is an aspect of His essence on the one hand, and (ii) the impossibility of the dissolution of divine will and the act on the other. However, not all theologians agree on this interpretation. In Khojazāda's opinion, both parties could concur on the principle's first implication (i), yet not all theologians approved of the second implication (ii), for it refutes the previously emphasized state of God's inactivity.

Having determined the point of dispute between them, Khojazāda continues his discussion in a dialogical argumentative move by presenting the views of those (i.e., the opposition) who embraced the notion of necessary in itself and countering with responses from the point of independent power. This dialogical move begins as follows:

[The opposition view:] If the first principle becomes an agent not by necessity but by power, then it would require a voluntary subject for God's power to relate not to things subject to His power but to one of them [...] it would require yet another, and thus there would necessarily emerge a chain of voluntary subjects. If there is no need for a voluntary subject, then it would require the independence of the possible beings from the agent. [...]

Response: We do not accept that power relates not to the things subject to it but to one, its need for a voluntary subject and the requirement of the chain, for the voluntary subject can be the will itself. [Thus] the will, eo ipso, relates to one of the two equal things without a need for a voluntary subject. ${ }^{46}$

This opposing view, conveyed by Khojazāda in this passage, claims that the notion of independent power obstructs the path to God's being because it holds that God's power needs a voluntary subject in order to attach itself to one of the multiple there would be no issue with the view of God's necessity in itself once accepted that the things emerged from God according to the divine will, after strongly underscoring that the real and true notion is that of independent power. Cf. Maḥmūd al-Iṣfahānī, Mațāli' al-anzār 'alā Ṭawāli' al-anwār (Istanbul: Sharika 'Ilmiyya, 1305/1888), 154.

46 Khojazāda, Tahāfut al-falāsifa, 6, 18-25. 
options and thereby engender the act. Since this voluntary subject also needs a subject for itself, a chain of subjects would occur. Khojazāda's brief response conveys that the chain would wither if the voluntary subject were identified by will, for:

[...] the chain would only be necessary if the relation of will requires another relation. But this is inadmissible, for if a voluntary agent engenders a thing with his will, the deed is what is subject to intention and thus needs the will that opted for it. Speaking of being qualified with the relation of will, it is a matter of concern when the said agent has an effect. But this will is not for the agent itself, but for the deed itself. Therefore, it does not need any other will in the agent. [...] Just like how there is no need for another necessity when the necessary engenders one thing by necessity and is qualified by necessity, the independent agent does not need another will on being qualified by it, when the independent agent engenders one thing by its will. ${ }^{47}$

He diligently distinguishes the aspects of will toward God and His work in order to demonstrate that the notion of independent power does not proffer a chain. The focal point of this distinction is the need to will. Thus, that which needs will in order to exist is not the voluntary agent, but rather the deed that was subject to the agent's will. This is why God does not need another will in order to be qualified with will. In this way, Khojazāda responds to the imputation of a chain (the opposition view) by identifying the voluntary subject as the divine will in the relation of the divine power to an act on the one hand, and demonstrating the non-necessity of another will for the divine will on the other.

He buttresses his stance by arguing that the distinction of necessary being/ contingent being brings to the fore the notion of independent power. In his opinion, deeming the beings external to God as contingent necessitates the existence of a voluntary subject that wills the existence of this potential being. If we speak of a being that wills one of the two equal options between existence and non-existence by its own will, then this being has to be an independent power, rather than necessary in itself. ${ }^{48}$ By the same token, he rejects the claim that the notion of independent power obstructs the path to God's being.

The most suggestive issue in the argumentative flow of the first part of Khojazāda's Tahäfut is his refraining from any expressions that would remind one of causality in the discussion of the relation between the God and the world, while arguing for the veracity of independent power, so that there is no notice of God as a

48 Ibid., 6, 29-7, 4. Cf. Gürbüz Deniz, Kelâm-Felsefe Tartışmaları: Tehâfütler Örneği (Ankara: Fecr Yayınlar1, 2009), 55-64. 
cause even with His will and volition. There is the marked influence of post-classical theologians in Khojazāda's caution, for the said theologians do not explain creation as a necessary causal relation in which God is the cause and the world is the effect. Instead, it follows a framework in which creation is not necessary with respect to God, but happens by His will and power. ${ }^{49}$ One of the manifest instances of this perspective is al-Jurjānī's statement:

In our opinion, there is neither a relation of causality nor of conditionality between things. On the contrary, all things emerge directly from the Independent just by His volition without any necessity. It is evident, once accepted, that God the Exalted is independent. ${ }^{50}$

When compared to the arguments in the first part of his Tahāfut, Khojazāda seems to expound on al-Jurjānī's perspective without any recourse to causality at the metaphysical level. Hence, he not only disputes necessary in itself and supports independent power in this part, but also distances himself from any reconciliatory approaches to the issue. Therefore, along with al-Jurjānī, he views the relation of God and the world not in terms of a causal relation, but as a creative relation centered on divine will and volition.

Another concept that comes into play in the argumentative flow's second stage is disposition. In his metaphysical explanations, Khojazāda does not display the exclusionary attitude that he assumed toward the implications that could pertain to causality and the notion of necessary in itself, to the concept of disposition entailing natural causality. Disposition is a concept that would be situated within the Avicennian theory of natural power and be closely related to the state of the natures in the sublunar world receiving the causal influence. ${ }^{51}$ Thus the notion of disposition operates in a framework presuming causality. In fact, as Qarabāghī, who lived a century after Khojazāda and annotated the latter's Tahāfut, quite justifiably pointed out, one could only speak of disposition once causality is assumed. ${ }^{52}$ In other words, assuming the existence of dispositions makes causality inevitable. Perusing the first and nineteenth theses, one could not detect any explanation by Khojazāda that en-

50 al-Jurjānī, Sharh al-Mawāqif, 3:193, 8-194, 1.

51 E.g., cf. Ibn Sīnā, Ilāhiyyāt-i Dānishnāma-i 'Alā'î, ed. Muhammad Mu'īn (Hamadan: Anjuman-i Āsāa va Mafākhir-i Farhangī, 2004), 159, 12-5. On the role of the concept of disposition in Avicennian natural philosophy, cf. İbrahim Halil Üçer, “Aristotle’s Dunamis Transformed: On Avicenna's Conception of Natural Isti 'dād and Tahayyu", Nazariyat 2, no. 3 (2015): 55-72. 
tirely repudiates disposition. Nevertheless, he supposes in $\mathrm{H}$ (2.b.ii) and $\mathrm{H}$ (2.b.iv) that extraordinary dispositions might appear, and therefore, dispositions could not be contained. However, rather than refuting disposition, this expression occasions the notion of what sort of relation exists between the cause and the effect, as well as the equivocality of the direction of causal effect in consequence. Some of the examples provided by Khojazāda in $\mathrm{H}$ (2.b.iii.i) and $\mathrm{H}$ (2.b.iv.i) to support his stance and thesis are also employed by al-Ghazālī in $G(2 . a . i . i i i . i)$ and $G(2 . a . i . i i i . i i)$.

In contrast to Khojazāda's stance, some theologians distanced themselves even further from the notion of disposition. al-Ījī and al-Jurjānī, to whom Khojazāda was related intellectually, are the first ones that come to mind. In his exposition of the philosopher's understanding of disposition, al-İjī reports that the dispositional potential in matter, according to them, renders matter amenable to causal effects. He then argues that this formulation was intended to invalidate the notion of independent power and therefore has to be rejected. ${ }^{53}$ Confirming al-İjì's statements, al-Jurjānī writes the following in his commentary:

This dispositional potential depends on the notion of necessity. This notion is based on the following view: The effusion of the principle encompasses all contingents, so that the particularity of the principle's lending existence to certain contingent things rather than the others originates from the difference concerning the disposition of things prone to effect. [However...] principle is the independent being that acts just as it wills. ${ }^{54}$

In this passage, al-Jurjānī points out that the disposition regarded by the philosophers as inherent in material beings is intimately related to the notion of necessity. This necessity, emerging out of the state of the reception of dispositions, does not remain only on the physical plane, but has intimated that it would be carried onto the metaphysical plane at the same time. In this context, al-Jurjāni argues that the idea of disposition is a result of the notion of necessary in itself, that it prevents God from being an independent power and obliges Him to act unidirectionally within the limits posed by the dispositions.

al-Jurjānī's aloof attitude vis-à-vis the dispositions elucidates the background of the objection raised by Qarabāghì. However, it is patent that the same aloofness cannot be attested in Khojazāda, for he does not entirely reject the idea of disposition even though he have stated the condition in $\mathrm{H}(2$.b.ii) and $\mathrm{H}$ (2.b.iv) that the 
dispositions cannot be enclosed. Furthermore, he displays an outlook based on an Avicennian sense of disposition in his discussion of the Prophet's self at the third stage of his argumentation in the nineteenth thesis. As will be indicated below, Khojazāda departs from the line of argument followed by al-Ījī and al-Jurjānī concerning the dispositions possessed by the Prophet's self.

Another matter in the second stage of Khojazāda's argumentation that can be considered related to the notion of disposition is the impossibility of transformation between two things with no common material denominator, as in $\mathrm{H}$ (2.c.i). As follows, things producing another effect by going beyond the circumscribed causal effect, or the occurrence of miracles that could be considered beyond the order of things following a cycle in the world, can happen according to the dispositions that only things could possess and that we could not encompass. As a result, while one can speak of the transformation of an accident into another as a miracle for instance, it could not be said of the transmutation of essences into accidents going beyond the notion of potential disposition. This state of affairs can be attested to at the third stage in G(3.b.iii). As a matter fact, al-Ghazālī offers more detailed explanations concerning what is impossible with respect to miracles. Especially in G(3.b) and G(3.b.i), he clearly tended toward the principles of logical non-contradiction and the impossibility of the third option and thus framed miracles along these principles.

Another issue that Khojazāda pronounced in $\mathrm{H}$ (2.b.iii), again concerning the notion of disposition, is the epistemological dimension of causality. In his opinion, since the dispositions cannot be enclosed, the supposed relation between the things cannot be known based on the determination of the disposition. But this does not mean that the relation between the cause and the effect cannot be known by the humans. Having deemed knowledge about the relation between the cause and the effect as necessary (ḍarūrī), Khojazāda assumes a more radical stance on this point than the one in al-Ghazālī's Tahäfut. Indeed, al-Ghazāli indicates the epistemological relation between the cause and the caused with the sentence "the knowledge [...is] impressed indelibly on our minds" in G(2.a.i.ii); however, he does not advance any further concept or justification on the necessity of this knowledge. His more explicit statements concerning the epistemological aspect of causality can be found in his Iqtișäd, in which he clearly reveals his acceptance of the epistemological relation between the cause and the caused by employing the verb $l-z-m .^{55}$

55 al-Ghazālī, al-Iqtișād fĩ al-i'tiqād, ed. İ. Agah Çubukçu, Hüseyin Atay (Ankara: Nur Matbaası, 1962), 224, 3-5. For an extended discussion of the necessity in causality in an epistemological sense, cf. Griffel, al-Ghazālì's Philosophical Theology, 175-213. 
The more emphatic use of "necessary" by Khojazāda than al-Ghazālī in H(2.b.iii) vis-à-vis the epistemological aspect of the causality, appears in the same context as in the al-Ījī-al-Jurjānī line:

The imagination of the need of the thing to another is necessary (darürī). This imagination, however, occurs spontaneously, for every person knows that he needs certain things and does not need some others. The imagination absolutely preceding the mandatory assent, however, is more fitting to be necessary. What a thing needed for its existence is called "its cause," and the thing in need is called "the caused."

Following the al-İjī-al-Jurjānī line on necessity with respect to the epistemological aspect of causality, the basis of the relation, for Khojazāda, is the perpetual continuity of the customary order of things and the God's creation due to this knowledge in us based on the continuity. Thus this knowledge, which depends on the order of things that we attested to is, according to Khojazāda, always possible to be altered with the deviation of the flow of causal order.

Khojazāda's refutation of the necessity of the relation between the cause and the caused ontologically, while retaining it epistemologically, can be read as an attempt ${ }^{57}$ to relieve the feeling of ontological insecurity that the assumption of the imminent alteration of the customary order of things would evoke on the one hand, and open up room for the possibility to do science without lapsing into contradictions between philosophical explanations on the other.

\section{The Third Stage of Khojazāda's Argumentation: The Explanation of Revelation and Miracles in an Avicennian Framework}

The third stage of Khojazāda's argumentation involves how esoteric and revelational knowledge would be obtained on the one hand, and how the prophets affect the beings in the world and could perform miracles on the other. Digressing from al-Ghazālì, the ground of the argumentation at this stage is supplied for the greater part by the Avicennian theory of the Prophet's soul. Morever, we may suggest that the arguments in $\mathrm{H}(3)$ follow the scheme concerning the forms of interaction between the corporeal and the spiritual beings related to the possibility of revelation and miracles in Avicenna's theory of prophethood in his Risāla al-fi'l wa-al-infi'àl. ${ }^{58}$

58 Ibn Sīnā, "Risāla al-fi'l wa-al-infi'āl," in Majmū' Rasā’il, ed. Zayn al-'Ābidīn al-Mūsawī (Hyderabad: Dā'irat al-Ma'ārif al-'Uthmāniyya, 1354/1935), 1-11. 
The first thing Avicenna mentioned in the scheme of this work is the influence and interaction in between the spiritual beings. This could be in the character of the interaction in between the supra-lunar distinct intellects ('uqūl mufäriq) as well as in the nature of the influence of the said intellects on human souls (nufüs bashariyya). ${ }^{59}$ According to him, this influence enables the human souls to reach out to hidden past, present, and future knowledge. ${ }^{60} \mathrm{He}$ supposes that this influence can only be inspired into ones predisposed (musta idda) to receive it. ${ }^{61}$ In his opinion, this influence coming from the supra-lunar intellects is called revelation if arrives in an "awakened" state (yaqaza), and "inspiration to the soul" (nafas fi alrūḥ) if in sleep. ${ }^{62}$

Khojazāda's arguments in $\mathrm{H}(3 . \mathrm{a})$ and H(3.b) and the examples he offered in H(3.a.i) and H(3.b.i) greatly parallels Avicenna's explanation of the influence of the supra-lunar intellects in his scheme on the human soul and his examples. The nuance here is in Khojazāda's conceptual preferences. He prefers to call the active spiritual being "sublime" and "distinct principles" (mabādī' 'āliyya/mufāriqa) in H(3.a) and (3.b); Avicenna called these "distinct intellects." This could be due to alRāzī's criticism of the Avicennian theory of emergence, including the supra-lunar distinct intellects. Since the expression "distinct intellects" explicitly reminded one of the Avicennian theory of emergence, he adopts the term "sublime principles,"63 which al-Rāzì did not oppose, as he used it in his Sharḥ al-Ishārāt.

Another nuance in the contact of $\mathrm{H}(3)$ between Khojazāda and Avicenna is that the latter called the influence of the distinct intellects on the human soul in the state of sleep "inspiration to soul," whereas the former names it observation (mushāhada) in H(3.a.i). In Avicenna's texts, this concept does not refer to mystical epistemology, whereas it does exactly that in Khojazāda's. ${ }^{64}$ Indeed, there is a strong reason for Khojazāda's use of the concept of observation as it descended to him, for it became a fundamental concept that represented the last stage of the process of the acquisition of mystical knowledge.

On the other hand, the arguments of both Avicenna and Khojazāda have several concepts in common, in addition the outline and the examples provided. Fore-

60 Ibid., 4, 7-10.

61 Ibid., 3, 8-11.

62 Ibid., 2, 8-11.

63 al-Rāzī, Sharh al-Ishārāt, 2:625, 18.

64 Cf. Dimitri Gutas, "Intuition and Thinking: The Evolving Structure of Avicenna's Epistemology," in Aspects of Avicenna, ed. Robert Wisnovsky (Princeton: Markus Wiener, 2001), 1-38. 
most is the disposition. Hence, the emphasis on the degree of human soul to be capable of receiving sublime influences in both arguments, were implicated with doublets of the same etymological root (ista'adda). Khojazāda's use of disposition in his own argumentation in H(3.a) distinguishes him from al-Jurjānī, who explicitly stated that there is no need for it in prophet's miracles when he criticized the philosophers' notion of miracles. ${ }^{65}$ But Khojazāda allows for the disposition of the Prophet's self in the context of revelation as a miracle, and therefore opts for Avicenna. Another common concept is defining the influence in the awakened state as revelation.

In $\mathrm{H}$ (3.c) and H(3.c.i), Khojazāda tries to demonstrate that spiritual beings could act on corporeal beings in order to build up to his argument for the possibility of a miracle whereby the Prophet's soul could affect the worldly beings. This argument could also be located in the scheme concerning the interactions between spiritual and corporeal beings in the same work of Avicenna, who states that spiritual powers could act on those beings made up of four elements and that some miracles are influences-interactions of this nature. ${ }^{66}$ The Prophet's motive soul that enacts this influence that engenders miracles could manipulate the material world and produce effects like storms, thunder, hurricanes, earthquakes, and the transformation of the staff into a serpent. ${ }^{67}$

The arguments and examples utilized by Khojazāda in H(3.d) and H(3.d.i) corresponded almost ad verbatim to the framework conveyed from Avicenna, and he defended the Avicenna's perspective that miracles were outputs of the Prophet's soul against which al-Ghazālī raised a probable objection in G(2.a.i.iii.iii). As a matter of fact, he did not criticize the philosophers' view of miracles as based on the Prophet's soul in G(2.a.i.iii.iii.i). ${ }^{68}$ Furthermore, he renders his own prophetic psychology in Avicennian terminology. ${ }^{69}$ But he suggests right before the seventeenth thesis that the philosophers' notion of miracles had some limits due to the dispositions and did not cover cases like the "transformation of the staff into a ser-

65 al-Jurjānī, Sharḥ al-Mawāqif, 8:251, 12-5.

66 Ibn Sīnā, "Risāla al-fíl wa-al-inficāl," 2, 12-15, 3, 19-21.

67 Ibid., 5, 2-4.

68 Frank Griffel, "Al-Ghazālī's Concept of Prophecy: The Introduction of Avicennan Psychology into Ašarite Theology," Arabic Sciences and Philosophy 14, no. 1 (2004): 101-44, 115.

69 Fazlur Rahman, Prophecy in Islam (London: George Allen \& Unwin Ltd, 1958), 95-8. Even though Griffel argues that there are Avicennian elements in al-Ghazāli's own theory of prophethood, he finds the attribution of the authorship of Ma'ärij al-quds fi madārij ma'rifa al-nafs, on which Rahman based his judgment, to al-Ghazālì doubtful. Cf. Griffel, "Al-Ghazālī’s Concept of Prophecy," 139. 
pent" and criticized them along these lines. ${ }^{70}$ However, the example of the "transformation of staff into a serpent" in Avicenna's Risāla al-fi'l wa-al-infi'āl invalidates this criticism of al-Ghazālī. Khojazāda also confirms this with his statement "the animal becomes inanimate and the inanimate animate" in $\mathrm{H}(3 . \mathrm{d}$.i) and thereby fortifies his objection to al-Ghazālī raised in H(1.c.i).

That Khojazāda left room for the themes of hidden knowledge in the Avicennian theory of prophethood and how miracles occurred, and that he also concluded the argumentative trajectory of causality, could also be read as a reply to the misconception popularized after al-Ghazāli that Avicenna did not treat the miracles conveyed from the prophets as a topic in order to keep his system of thought consistent.

\section{Conclusion}

Khojazāda's treatment of causality in Tahäfut, when considered in the context of al-Ghazāli, exhibits certain particularities. These could be located in the argumentative patterns and contents as well as attested to by his deployment of the novel conceptual framework that emerged in the debates of causality after alGhazālì. The most noticeable matter in the argumentative content is Khojazāda's critique of al-Ghazāli. While the latter supposed that the philosophers denied miracles, Khojazāda tries to debunk this claim by quoting a passage from Avicenna's al-Ishārāt that stated the possibility of supernatural events. Besides, Khojazāda based the third stage of his argumentation on Avicennian psychology rather than al-Ghazālì. Hence, it is a practical refutation of the bias formed after al-Ghazālì.

In parallel with al-Jurjānī, Khojazāda distinguishes between cause and reason when discussing causality. Moreover, he attaches the adjective "common" before reason in order to stress this distinction. By doing so, he provides a conceptual base that enables him to display the different levels of causality on the physical plane. In addition, Khojazāda utilizes the distinction of complete-incomplete cause that was popularized during the thirteenth century, in contradistinction to al-Ghazāli. This distinction opens up enough room to demonstrate that nature is not a sufficient cause to put forth an effect.

Primarily, what Khojazāda concurred with al-Ghazālī in the context of the problem of causality is the subject of the non-existence of an ontologically necessary relationship between the cause and the caused in the world. This concurrence 
aims at asserted existence of a necessary link, rather than a refutation of a relation between them. On the other hand, the epistemological link, which they also concurred in different measures, was stated more explicitly in Khojazāda's Tahāfut as leaning toward necessity when compared to al-Ghazālī. Hence, while al-Ghazālī speaks of this relation as being "impressed indelibly on our minds," Khojazāda follows al-Jurjānī and manifestly considers it to be "necessary."

Khojazāda refutes the notion of necessary in itself, which corresponded to the metaphysical aspect of the conception of necessary causality held by al-Ghazāli. Moreover, he rejects the perspective that views God as a cause, for it leads to the possibility that would impel Him to act. Instead, he adopts the notion of an independent power centered in God's will and power, one that retains the possibility of His inactivity. Khojazāda's most patent criticism of Avicennia's notion of causality appears at this point. But when the physical dimension is of concern, Khojazāda assumes a more reconciliatory attitude between the philosophers and the theologians. On this point, he attests to the existence of dispositions in the Avicennian sense concerning the physical causal relations on the one hand, and suggests the inability to encompass dispositions and thus the inability to limit the natures with certain dispositions on the other. Consequently, he both confirms the existence of the causal relations in physical processes and prevents the aspect of God's intervention into the world by His will and power from being marred.

\section{Bibliography}

al-Abharī, Athīr al-Dīn. Kashf al-ḥaqā’iq fì tahrīr al-daqā’iq. Ed. Hüseyin Sarıŏlu. İstanbul: Çantay Kitabevi, 1998.

Altaş, Eşref. Fahreddin er-Râzînnin İbn Sînâ Yorumu ve Eleştirisi. İstanbul: İz Yayıncılık, 2009.

al-Baghdādī, Abū al-Barakāt. al-Kitāb al-Mu'tabar fí al-hịkma. 3 vols. Hyderabad: Jam'iyya Dā'irat al-Ma'ârif al'Uthmāniyya, 1357/1938.

Demir, Osman. Kelâmda Nedensellik: İlk Dönem Kelâmcılarında Tabiat ve İnsan. İstanbul: Klasik, 2015.

Deniz, Gürbüz. Kelâm-Felsefe Tartışmaları: Tehâfütler Örneği. Ankara: Fecr Yayınları, 2009.

al-Ghazālī, Abū Ḥāmid. Tahāfut al-falāsifa. Ed. Sulaymān Dunyā. Cairo: Dār al-Maāāif, 1980.

al-Iqtișād fi al-i'tiqād. Ed. I. Agah Çubukçu, Hüseyin Atay. Ankara: Nur Matbaası, 1962.

Griffel, Frank. "al-Ghazāli’s Concept of Prophecy: The Introduction of Avicennan Psychology into Aš‘arite Theology." Arabic Sciences and Philosophy 14, no. 1 (2004): 101-44.

_—_. al-Ghazālī's Philosophical Theology. Oxford: Oxford University Press, 2009.

Gutas, Dimitri. “Intuition and Thinking: The Evolving Structure of Avicenna's Epistemology." In Aspects of Avicenna. Ed. Robert Wisnovsky, 1-38. Princeton: Markus Wiener, 2001.

Güzel, Abdurrahim. Karabağ̂̀ ve Tehâfüt’ü. Ankara: Kültür Bakanlığı, 1991.

Ibn Kamāl Pāshā, Shams al-Dīn Aḥmad. Ḥāshiya 'alā Tahāfut. Süleymaniye Library, MS Hasan Hüsnü Paşa 1235, 
$1 \mathrm{a}-53 \mathrm{~b}$.

Kemal Paşazâde. Tehâfüt Hâşiyesi (Hāşiya 'alā Tahāfut al-falāsifa). Trans. Ahmet Arslan. Ankara: Kültür ve Turizm Bakanlı̆̆ı, 1987.

Ibn Manzūur. Lisān al-'arab. Beirut: Dār Șādir, 1994.

Ibn Rushd. Tahāfut al-tahāfut. Ed. Sulaymān Dunyā. 2 vols. Cairo: Dār al-Ma'ārif, 1965.

Ibn Sīnā. Ilāhiyyāt-i Dānishnāma-i 'Alā’̀̄. Ed. Muḥammad Mu'īn. Hamadan: Anjuman-i Āthār va Mafākhir-i Farhangī, 2004.

___. al-Ishārāt wa-al-tanbīhāt (al-Tașawwuf). Ed. Sulaymān Dunyā. 4 vols. Cairo: Dār al-Ma'ārif, 1968.

. al-Mabda' wa-al-ma'ād. Ed. 'Abd Allāh Nūrānī. Tehran: Mu'assasa-i Muṭāla'āt-i Islāmī, 1363/1984.

. “Risāla al-fi'l wa-al-infi‘āl." In Majmū' Rasā’il. Ed. Zayn al-'Ābidīn al-Mūsawī, 1-11. Hyderabad: Dā'ira alMa‘ārif al-'Uthmāniyya, 1354/1935.

al-Ișfahānī, Maḥmūd. Mațāli' al-anzāàr 'alā Țawāli' al-anwār. Istanbul: Sharika 'Ilmiyya, 1305/1888.

al-Jurjānī, Sayyid Sharīf. Sharḥ al-Mawāqif. Ed. Maḥmūd 'Umar al-Dimyāțī. 8 vols. Beirut: Dār al-Kutub al-'Ilmiyya, 1998.

. al-Ta'rīfāt. Ed. 'Abd al-Raḥmān ‘Umayra. Beirut: 'Ālam al-Kutub, 1987.

Karadaş, Cağfer. “Hocazâde'nin Tehâfüt'ünde Sebeplilik Meselesi." In Uluslararası Hocazâde Sempozyumu, 22-24 Ekim 2010, Bursa: Bildiriler. Eds. Tevfik Yücedoğru, Orhan Ş. Koloğlu, U. Murat Kılavuz, and Kadir Gömbeyaz, 16373. Bursa: Bursa Büyükşehir Belediyesi, 2011.

al-Kātibī, Najm al-Dīn, and Shams al-Dīn Mubārakshāh. Hikmat al-'ayn wa-al-sharḥ. Mashhad: Dānishgāh-i Firdawsī, 1974

Khojazāda, Muṣlih al-Dīn. Kalimāt fì bahth al-îlla wa-al-ma'tūl. Süleymaniye Library, MS Esad Efendi 1161, 99a.

. Tahāfut al-falāsifa. Millet Library, MS Feyzullah Efendi 1182: 1a-145a.

. Tahāfut al-falāsifa. Cairo: al-Mațba'a al-I'lāmiyya, 1303/1885.

Ta'līqāt 'alā Sharḥ al-Mawāqif. Atıf Efendi Library MS 1219, 1a-104b.

Kılıç, Muhammet Fatih. “İbn Sînâ’nın Sebeplik Teorisi.” PhD diss., Istanbul University, 2013.

van Lit, L. W. C. "An Ottoman Commentary Tradition on Ghazālīs Tahāfut al-falāsifa. Preliminary Observations." Oriens 43, no. 3-4 (2015): 368-413

Önal, Emre. “Hocazade ve Haşiya ala Şarh Hidayet al-Hikma Adlı Eseri.” MA thesis, Marmara University, 2006.

Qarabāghī, Muhyī al-Dīn. Ta'līqa 'alā Tahāfut al-falāsifa li-Khojazāda. Süleymaniye Library, MS Hasan Hüsnü Paşa 959, 1-17.

Rahman, Fazlur. Prophecy in Islam. London: George Allen \& Unwin, 1958.

al-Rāzī, Fakhr al-Dīn. Sharḥ al-Ishārāt wa-al-tanbīhāt. Ed. 'Alī Ridā Najafzāda. 2 vols. Tehran: Anjuman-i Āthār va Mafākhir-i Farhangī, 2005.

Sinān Pāshā. Kalimāt fì baḥth al-'illa wa-al-ma'lūl. Süleymaniye Library, MS Esad Efendi 1161, 98a.

al-Suhrawardī, Shihāb al-Dīn Yahyā. Kitāb al-Lamahāt. Ed. Emile Maalouf. Beirut: Dar al-Nahār, 1969.

Shahrazūrī, Shams al-Dīn. Rasāill al-Shajara al-ilāhiyya. Ed. Necip Görgün. İstanbul: Elif Yayınları, 2004.

al-Taftāzānī, Sa'd al-Dīn. Sharḥ al-Maqāṣid. Ed. Abd al-Raḥmān 'Umayra. 4 vols. Beirut: 'Ālam al-Kutub, 1998.

al-Ṭūsī, 'Alī. Kitāb al-dhakhïra. Hyderabad: Dā’ira al-Ma'ārif al-'Uthmāniyya, 1925.

Tahāfut al-falāsifa. Ed. Riḍā Sa‘̄āda. Beirut: al-Dār al-'Ālamiyya, 1981. 
al-Ṭūsī, Nașīr al-Dīn. Talkhīṣ al-Muhașșal. Ed. 'Abd Allāh Nūrānī. Tehran: Mu’assasa-i Muṭāla'āt-i Islāmī, 1980.

Türker, Ömer. “Giriş: Seyyid Şerif Cürcânî Düşüncesi.” In Şerhu'l-Mevâkıf: Mevâkıf Şerhi. Trans. Ömer Türker, 1:1789. İstanbul: Türkiye Yazma Eserler Kurumu Başkanlığı, 2015.

Üçer, İbrahim Halil. “Aristotle’s Dunamis Transformed: On Avicenna's Conception of Natural Isti 'dād and Tahayyu'." Nazariyat 2, no. 3 (2015): 37-76.

Üsküdârî, Mehmed Emin. Telhîsu Tehâfüti'l-hukemâ. Ed. and trans. Kamuran Gökdağ. İstanbul: Türkiye Yazma Eserler Kurumu Başkanlığı, 2014. 